Illinois State University

ISU ReD: Research and eData

Theses and Dissertations

4-23-2021

\title{
'Give Us More to See': A Feminist and Queer Look at Stephen Sondheim
}

Kevin P. Goffard

Illinois State University, kevingoffard@icloud.com

Follow this and additional works at: https://ir.library.illinoisstate.edu/etd

\section{Recommended Citation}

Goffard, Kevin P., "'Give Us More to See': A Feminist and Queer Look at Stephen Sondheim" (2021). Theses and Dissertations. 1436.

https://ir.library.illinoisstate.edu/etd/1436

This Thesis is brought to you for free and open access by ISU ReD: Research and eData. It has been accepted for inclusion in Theses and Dissertations by an authorized administrator of ISU ReD: Research and eData. For more information, please contact ISUReD@ilstu.edu. 
'GIVE US MORE TO SEE': A FEMINIST AND QUEER LOOK AT STEPHEN SONDHEIM

\section{KEVIN GOFFARD}

88 Pages

As our world begins to reopen following the closure due to the COVID-19 pandemic, many industries — including the theatre — will be left with starting to get back to a new normal. Along with the COVID-19 pandemic, theatre also faced another reckoning within the industry: despite often being a place of refuge for many marginalized groups, racism, discrimination, and harassment has been a common occurrence within the industry. As the theatre community looks forward, many are yearning for a more inclusive theatre community. As such, the theatre community will be tasked with an overarching question of: what will our new normal look like? Through textual analysis and how underrepresented populations are represented, I will argue that Stephen Sondheim should be included in the theatrical cannon as we move into this new normal. To accomplish this, I will argue how Sondheim's shows have historically and contemporarily rejected societal and cultural norms for women and folks of differing sexualities and have instead portrayed them as strong characters. As such, I will ultimately argue that Sondheim is political theatre and helps to confront sexist and homophobic ideologies that are counter to an inclusive world.

KEYWORDS: Sondheim; Musical Theatre; Feminism; Queer Theory; Sexuality; Gypsy; A Little Night Music; Into the Woods; Company; Sweeney Todd: The Demon Barber of Fleet Street; Road Show 
KEVIN GOFFARD

A Thesis Submitted in Partial Fulfillment of the Requirements for the Degree of

\section{MASTER OF SCIENCE}

School of Theatre and Dance

\section{ILLINOIS STATE UNIVERSITY}


(C) 2021 Kevin Goffard 
'GIVE US MORE TO SEE': A FEMINIST AND QUEER LOOK AT STEPHEN SONDHEIM

KEVIN GOFFARD

COMMITTEE MEMBERS:

Ann Haugo, Co-Chair

Kee-Yoon Nahm, Co-Chair

Michael J. Vetere III

Robert McLaughlin 


\section{ACKNOWLEDGMENTS}

I would first like to thank my committee members for their guidance and support throughout this process. To Dr. Ann Haugo, I would like to thank you for your years of guidance, support, and friendship. Thank you for always allowing me to pursue my various passions and always supporting me through my years at ISU. To Dr. Kee-Yoon Nahm, I would like to thank you for your support and guidance and for igniting my love for dramaturgy and for always encouraging me to share my work with others. To Dr. Michael Vetere, I will be forever grateful for your constant reminders and lessons in the importance of having fun and loving what you do. Your support through my undergraduate and graduate years have been critical to my success. Finally, to Dr. Robert McLaughlin who shares my love and passion for Sondheim and for being one of the first to show me that Sondheim and the American Musical Theatre are worthy of scholarly study.

I would like to thank all my past and current instructors at Illinois State University. Each one has impacted me in a positive way that has brought me to this point. Special thanks go out to former and current Theatre Studies professors who have especially made a profound impact on my choice to pursue this field. These professors who have been major influences in my life include Dr. Will Daddario, Dr. John Poole, Dr. Li Zeng, and Dr. Leslie Sloan Orr.

I would like to thank my family and friends for their love, support, and guidance through this process. I would like to especially thank my mom, Patti; my grandma, Lorraine; and my brother, Kyle, for their patience with me this past semester and to help me avoid the pitfalls of procrastination. It is to them that this thesis is dedicated.

The COVID-19 pandemic made the writing of this thesis especially interesting, including making it difficult to acquire research through traditional means. Research for this thesis was 
funded in part by a grant from Illinois State University Friends of the Arts. I wish to thank Friends of the Arts for their generosity and commitment to the students of the Wonsook Kim College of Fine Arts.

My gratitude also must go out to my student employees who have pushed and support me just as much, if not harder, than I have in their academic pursuits. I also wish to thank my supervisor, Tim McCue, and mentor Dr. Jamie Neville for their unrelentless support and check in throughout this process.

Finally, I wish to thank Stephen Sondheim for creating a cannon of work that rivals the best of any theatrical work.

K.G. 


\section{CONTENTS}

Page

ACKNOWLEDGMENTS

CHAPTER I: THE PROBLEM AND ITS BACKGROUND 1

$\begin{array}{ll}\text { Background } & 4\end{array}$

Sondheim in American Musical Theatre History $\quad 4$

Feminism \& Feminist Theory $\quad 6$

Queer Theory 9

$\begin{array}{ll}\text { Limitations of the Study } & 12\end{array}$

$\begin{array}{ll}\text { Literature Review } & 13\end{array}$

$\begin{array}{ll}\text { Methodologies } & 17\end{array}$

$\begin{array}{ll}\text { Chapter Overview } & 17\end{array}$

CHAPTER II: SONDHEIM THROUGH A FEMINIST LENS 19

$\begin{array}{ll}\text { Gypsy } & 20\end{array}$

A Little Night Music

Into the Woods $\quad 42$

$\begin{array}{ll}\text { Conclusion } & 50\end{array}$

CHAPTER III: SONDHEIM THROUGH A QUEER LENS 52

$\begin{array}{ll}\text { Company } & 55\end{array}$

Sweeney Todd: The Demon Barber of Fleet Street $\quad 64$

$\begin{array}{ll}\text { Road Show } & 69\end{array}$

$\begin{array}{ll}\text { Conclusion } & 76\end{array}$

CHAPTER IV: SUMMARY, CONCLUSION, AND RECOMMENDATIONS 78 
WORKS CITED 


\section{CHAPTER I: THE PROBLEM AND ITS BACKGROUND}

On March $12^{\text {th }}, 2020$, like most of our world, Broadway went dark due to the Coronavirus (SARS-CoV-2; “COVID-19”) Pandemic. While Broadway has gone dark before, such as for natural disasters, or after the September 11, 2001 attacks, for the most part, Broadway has stayed on-surviving world wars, economic recissions, and social upheaval. The saying, "The Show Must Go On" is synonymous with Broadway. Even in our darkest days, many have turned to the arts and America's artform for a sense of hope and optimism. Over a year later, Broadway — often thought of as the "heart of America's theater industry" (Paulson 1)—remains dark. It will have been 539 days when Broadway finally reopens, and while that is encouraging for the recovery of the industry — dozens and hundreds of theatre companies across the country will stay dark forever.

The Show Must Go On is a phrase that will take new meaning upon Broadway reopening. 2020 will not just be a year in history due to the global shutdown due to the pandemic but will be an important year for the movement for social justice. With the world coming to reckon the rampant sexism and harassment that was exposed with the \#MeToo movement, \#BlackLivesMatter obtained global attention for the world to reckon with the racism and discrimination that still exists within global societies. This also rekindled within the American Broadway Musical and the theatre industry. Theatre faced a call from artists across the country and across the world to reflect on the discriminatory actions of the past and to set a more equal path towards the future. When "The Show Must Go On", advocates want to see a more inclusive artform where sexual harassment, discrimination or racism is no longer tolerated. The American Musical, like many institutions, has historically been a white, heterogendered institution, despite it also being a place of refuge for many marginalized groups. As a result, for years, 
discrimination and harassment because one's race, sex, or gender identity has become a sort of normalcy for the Broadway Musical and the American theatre. As we begin to look toward our "new normal" it begs us to ask: What will our new normal look like?

Through textual analysis and how underrepresented populations are represented, I will argue that Stephen Sondheim should be included in the theatrical cannon as we move into this new normal. To accomplish this, I will argue how Sondheim's shows have historically and contemporarily rejected societal and cultural norms for women and folks of differing sexualities and have instead portrayed them as strong characters. As such, I will argue that Sondheim is political theatre.

The name Stephen Sondheim is synonymous with the American Musical Theatre. Considered to be one of the great American Musical Theatre artists, Sondheim is responsible for some of the most beloved musicals, including Passion, Company, Into the Woods, Sweeney Todd: The Demon Barber of Fleet Street, and Saturday in the Park with George. Among the hundreds of accolades for his work, Sondheim is the recipient of eight Tony Awards, eight Grammy Awards, an Academy Award, a Laurence Olivier Award, a Pulitzer Prize, a Kennedy Center Honor, and a Presidential Medal of Freedom. Sondheim has also been inducted in the Songwriter's Hall of Fame, while also having two theatres named after him, one on Broadway and one on the West End.

There is a lot of information published on Sondheim and his contributions to the American Musical. I wish to join in conversations with these scholars by asserting that Sondheim and his theatrical cannon is political theatre. To understand this, one must understand political theatre. According to the New South Wales Department of Education, a simplified definition of political theatre is: "Political theatre is a term that has been used to refer to different forms, 
theatrical styles or performances that comments on political/social/cultural issues, political action or protest that has a theatrical quality to it" (New 1). Taking this definition into consideration, for me, political theatre needs to have two main components: (1) a performative art with a theatrical quality (though it need not be a 'dramatic work') and (2) comments on cultural, social, or political issues. By using this definition for my study, I will utilize queer and feminist theory to analyze Sondheim's work and argue that these works are indeed political theatre.

One of the unique advantages that I have when analyzing Sondheim's life and work is the distance in time from the decades in which he lived and worked. These decades have been filled with cultural, artistic, and societal shifts, strife, advances, and setbacks. Because there is a gap of time between when the shows were written and today, there are a lot of historical artifacts, including pictures, recordings, interviews, scripts, annotated notes, and more that can help contextualize the time in which Sondheim was writing, as well as the period the shows were set in. By being able to do this contextualization, this provides me with a unique opportunity to explore how certain elements of the time, or acceptance and rejection of societal norms of the time, have made their way into his shows and will allow me to place my analysis within a broader societal and artistic lens.

The analysis that I am conducting could help lead future researchers to dive into other musical theatre artists. Indeed, we might be able to further understand the discrimination that has run rampant within the theatre in terms of race, gender, sexuality and more. We can also explore how greater social movements (such as the Civil Rights, Gay Rights, Chicano Rights, etc.) have helped to challenge, address, or support the norms of society and theatre. While this thesis will specifically focus on gender and sexuality, there is ample amount of room for additional intersectional studies to be completed on this topic. This thesis, then, will not only contribute to 
the literature in the fields of Sondheim studies and theatre, but it will also add to the body of work within sexuality, gender, women, and masculinity studies. This thesis will, most importantly, encourage others to conduct a closer examination of the canon of theatrical work as we begin to create a 'new normal'.

\section{Background}

\section{Sondheim in American Musical Theatre History}

The American musical theatre is one of the few authentic American artforms. As Stacy Wolf asserts, the American Musical was "Born from a mélange of performance forms that included opera and operetta, vaudeville and burlesque, minstrelsy, and jazz...” (Wolf 3). While Wolf asserts that the American musical has always sought to be merely entertainment and make money rather than political, or social change, they have in a unique twist of fates to have influenced American culture just as much, if not more, than any other artform. Wolf further explains, "Reflecting, refracting, and shaping U.S. culture since the early twentieth century, musicals converse with shifting dynamics of gender and sexuality, ethnicity and race, and the very question of what it means to be American and to be human. The musical explores identity, self-determination, and the American dream" (Wolf 3). I wish to slightly rebuke Wolf by arguing that while the American musical might not have been seen as a political tool, it indeed has always been political in some way.

For the sake of simplicity, the American Musical Theatre can be broken up into several distinct time periods. As each period came, new developments in the structure of the musical emerged. One of the important developments for the structure of the musical is often referred to as the "Golden Age" which spans from approximately 1943-1959. This time is important to the development of the musical because it saw a new approach in how shows were created. Works 
from different artists, such as Rodgers and Hammerstein, moved this new approach and helped to make it mainstream. In these new works, we begin to see the narrative storytelling that has dominated the musical theatre stage ever since. However, one of the unintended side effects of this new style was the prevalence of white heterosexual ideals which were consistent with American society at the time. These ideals included societal and cultural norms, which limited opportunities for women and minoritized communities.

Another important contribution to come from this time was Hammerstein's protégé, Stephen Sondheim. Stephen Sondheim was born on March 22, 1930 to Herbert and Janet Sondheim. Despite being born into a well-off family in the middle of New York City, Sondheim's upbringing was anything short of being functional. Whether due to the eventual downfall between Janet and Herbert (Sondheim assumes that it could be possible that his father never loved his mother and only needed a designer), to his mom's “...domineering, controlling and overpossessive..." (Secrest 31) attitude towards her son. This coupled with being gay as well as the stress that came with trying to fit into society's norms had prolonged effects on Sondheim. A reluctance of trust, especially among women, as well as his hesitation on issues surrounding marriages, child-parent relationships, and society's view of differing identities, all existed, leaving Sondheim grappling for his place within this world. All these prolonged effects not only effected Sondheim on a personal level but would also have a profound effect on his work as well.

While his biological parents might not have been the ideal parents, Sondheim did find a parental figure in Oscar Hammerstein. Oscar Hammerstein was a musical theatre lyricist, who not only helped fill the parental void that existed within Sondheim's life, but also helped fill the professional mentor void that Sondheim needed as a beginning artist. Hammerstein's work was revolutionary as it moved the American musical from merely just a collection of songs for 
entertainment, but really transformed it by adding a story strung throughout the production that connected the work from start to finish. During an interview on Playbill.com with Sondheim, interviewer Kenneth Jones states that "Sondheim recognized Hammerstein's revolution (it began with Show Boat and continued with Hammerstein's musicals with Richard Rodgers Oklahoma!, Carousel, South Pacific, The King and I and others), but Sondheim sought to avoid Hammerstein's reliance on holdovers from the operetta era (purple prose and unnatural phrasing) and pushed for delving deeper into the psychology of characters" (Jones 1). This focus on diving deeper into the world helped Sondheim begin to deviate away from the structure of musicals that Rodgers and Hammerstein had developed. Instead, his deviation (while still taking with him important lessons from Hammerstein) had allowed him to venture into new territories, such as the concept musical. The concept musical is a musical that focuses on a theme, not necessarily focusing solely on a narrative plot structure. It is understanding then, to see the connection between the dysfunctions of Sondheim's upbringing and their long-term effects and their presence in several themes and plot points of his shows.

\section{Feminism \& Feminist Theory}

Feminist and social activist Gloria Jean Watkins, known as bell hooks, defines Feminism as "a movement to end sexism, sexist exploitation, and oppression" (hooks 1). For many, feminism has often been taught and discussed as differing "waves" being broken up into first, second, and third waves. With each consecutive wave moving beyond the "finding a seat at the table' to 'let us build a new table where there is room for us' to 'let us change the system so that all people are at the table'. While this is beneficial, this definition is also simple. It makes it seem that there are only three theories when it comes to feminist thought, and the mere fact is that simply is not true. Additionally, the non-inclusivity of many of these waves make it impossible 
for a full knowledge of feminist theories from marginalized groups. Instead, I feel that it is better to look at groupings rather than waves. Sociologist Judith Lorber groups feminist thoughts or ideologies into three main groupings: gender reform feminisms, gender resistant feminisms, and gender revolution feminisms. In her work The Variety of Feminisms and their Contributions to Gender Equality (1997), Lorber describes each of these different groupings as well as gives examples of differing identities that can be associated with each grouping.

The first grouping is the gender form feminisms and include feminist ideologies such as liberal, Marxists and socialist feminism. The purpose behind this group is more focused at the individual and economic dependence levels. That is, it poses the question that if women and men are closely similar — what difference does it make if a job is performed by men or women? It also poses a further stance that the women are oppressed because of the economic dependence on the husband and that state economic needs will come before the needs of the woman.

The second grouping is gender resistant feminisms. Included in this grouping is "radical feminism, lesbian feminism, psychoanalytical feminism, and standpoint feminism" (Lorber 16). The purpose behind this grouping is viewing the specific actions or cultural barriers that keep women at a certain position. Partially forming due to more women entering male-dominated terrains, this grouping focus on "These "microinequities" of everyday life -- being ignored and interrupted, not getting credit for competence or good performance, being passed over for jobs that involve taking charge -- crystallize into a pattern that insidiously wears women down" (Lorber 16).

The third and final grouping is gender evolution feminisms. Lorber's third group is one that traditional feminist teachings might consider to be 'third' or 'fourth wave' feminism. Lorber states: 
These feminisms deconstruct the interlocking structures of power and privilege that make one group of men dominant, and range everyone else in a complex ladder of increasing disadvantage. They also analyze how cultural productions, especially in the mass media, justify and normalize inequality and subordinating practices. These feminisms thus have the revolutionary potential of destabilizing the structure and values of the dominant social order. (Lorber 25).

Lorber goes on to explain that different ideologies of feminism, including "multi-ethnic feminism, men's feminism, social construction feminism, post-modern feminism and queer theory" (Lorber 25) all exist within this grouping. By viewing the American Musical Theatre as a cultural production, we can begin to see the importance of Lorber's theory to my study. If the American Musical had been used in history as a tool to normalize inequality and uphold traditions that lead to sexist oppression, then artists or works that rejected those norms, or critiqued them, could be engaging in feminist work. This means that they are working to potentially destabilize the dominant foundation on which these systems were built and begin to break down these barriers. Through my study, I will argue how Sondheim engages in the latter, and uses his shows as a tool to break down these cultural and societal barriers.

Feminism is important with contemporary studies of the musical. In recent years, there is much evidence to suggest that the American musical is still a predominantly male institution. In a report titled Broadway by the Numbers, ProductionPro lays the bare numbers out. Data from the 2019 season show that out of 365 titled characters, $61 \%$ were male, $32 \%$ were female, $0.27 \%$ were 'nonbinary plural', and $7.1 \%$ were of an 'unspecified gender'. Seven shows had 0 females as part of their production teams, only six shows had females making up 50\% or more of their production teams while males dominated the directing, choreographer, and writer categories, 
each comprising of $87 \%, 76 \%$, and $85 \%$, respectively. The exceptions to this are costume, company manager, wardrobe, and hair \& makeup roles, otherwise males dominated every other production role available. This lack of representation both on and off the stage help to illustrate why feminism is an important tool to use as we chart our new future.

\section{Queer Theory}

Queer theory is a relatively new field within academia and can find its roots based on post-structuralist feminist theory. Sociologist Jodie Taylor defined queer theory as the following:

Queer theory is meant to agitate, subvert and disrupt notions of the natural, normative and the canonical, problematizing historical meta-narratives, deconstructing social privilege, hierarchies and power relations. It resists the logic of heterosexual hegemony: that is, the idea that our biological sex should determine the way we express our gender and our sexual desires...It deconstructs heteronormative power relations: that is, the cultural bias towards opposite sex attraction and the social privileges afforded to heterosexuality...Furthermore, it critiques the rise of homonormativity, which describes the neoliberal sexual politics of assimilated lesbian and gay minorities (Taylor 195).

One of the first scholars to define queerness in this way was Teresa de Lauretis'. In her influential article "Queer Theory: Lesbian and Gay Sexualities", de Lauretis helps break down this definition into three main points: "refusing heterosexuality as the benchmark for sexual formations, a challenge to the belief that lesbian and gay studies is one single entity, and a strong focus on the multiple ways that race shapes sexual bias" (University 1). Since its academia formation in the early 1990's, there have been some core theorists that have contributed to queer theory. 
Michael Foucault, while not necessarily writing specifically about queer theory, has led to incredible contributions to the field. Operating in a school of thought known as poststructuralism, Foucault has produced many important works, perhaps most importantly his work The History of Sexuality (1976). In his work, Foucault exerts: "The society that emerged in the nineteenth century — bourgeois, capitalist, or industrial society, call it what you will— did not confront sex with a fundamental refusal of recognition. On the contrary, it put into operation an entire machinery for producing true discourses concerning it. Not only did it speak of sex and compel everyone to do so; it also set out to formulate the uniform truth of sex" (Foucault 69). In other words, Foucault argues that society has formulated a certain 'truth' regarding sexuality and that any deviation, ever so subtle has led to one being an 'other' or as pervasive. Foucault argues against this notion that sexuality can be clearly defined as government and what society has made us believe.

Gayle Rubin is another core theorist that lends well to this study. Gayle Rubin, whose influential work includes Thinking Sex, believes that sexuality:

...is organized into systems of power, which reward and encourage some individuals and activities, while punishing and suppressing others. Like the capitalist organization of labour and its distribution of rewards and powers, the modern sexual system has been the object of political struggle since it emerged and as it has evolved (Rubin 171).

Like Foucault, Rubin does not believe that biology should determine sexuality. Rubin is increasingly interested in how systems of power have created ideas that certain sexualities are more valuable than others. Deviation from those sexualities deemed valuable presents oppression to that individual. Rubin's work, along with Foucault also give rise to philosopher Judith Butler. 
In her work, Gender Trouble, claims “...that gender, rather than being an essential quality following from biological sex, or an inherent identity, is an act which grows out of, reinforces, and is reinforced by, societal norms and creates the illusion of binary sex" (Morgenroth 1). As with Rubin and Foucault, Butler rejects the notion that sexuality, and in connection, gender cannot be clearly defined and has only done so because of society which rewards those that have been determined as "normal" and oppresses those seen as "abnormal".

Again, by viewing the American Musical Theatre as a cultural production, we can begin to see the importance of queer theory to my study. As a mode of a cultural production, it can be a tool that can be used to either reinforce or reject societal and cultural norms and standards with regards to sexuality. In other words, it can be used as a tool to encourage positive behaviors (for example: heterosexuality, cis-gendered, etc.); while suppressing or discouraging deviant behaviors (for example: gay, lesbian, transgender, etc.). If the American musical had been used in the past to promote heterosexism ideals, then artists or shows who reject heterosexism as an ideal could be engaging in queer theory. I will argue that Sondheim has mostly engaged in rejecting cultural and societal norms with regards to sexuality. While data is not readily available showing LGBTQ+ representation on the American musical stage, there is data available for a comparable period in a report conducted by GLADD (Gay \& Lesbian Alliance Against Defamation) that focuses on film and TV portrayals. However, even there, they witnessed year-over-year decreases of lesbian, gay, and bisexual representation in film, with only a slight improvement for those identifying as trans.

It is important to note that while the word might be used now as an "umbrella term", the word 'queer' has had a long history and had historically been used as a derogatory term. While recent years have seen some of the LGBTQ+ community reclaim the word, it is important to note 
that queer does not represent a singular sexual orientation and gender identity. Instead, it is used to represent any identity that is not straight or cis-gendered. Specifically, it can be thought of as a rejection of labels that are assigned in our society with regards to gender and sexuality. Gay, on the other hand is the emotional and/or sexual attraction of one "man" to another "man"; whereas Lesbian is the emotion and/or sexual attraction of one "woman" to another "woman". I place man and woman in quotation marks to acknowledge the transphobia that is prevalent among some gay and/or lesbian communities and the refusal of some in the community to see gender beyond a binary system of "man" and "woman". Within my study, "gay" will be used specifically with regards to a "man" having a sexual and/or emotional attraction to another "man", while "queer" will be used to represent ideals that are outside of the "normal" labels of society with regards to gender and sexuality.

\section{Limitations of the Study}

I am a cis-gender, white male. With this, I bring privilege and life experiences that could alter how I interpret theory and how I apply it to Sondheim's work and the American Musical Theatre at large. Also, I live in a different social and political world than when and where the shows that I will be exploring were written. Because I am using relatively new theories, it is imperative that I also consider the time when these shows were written and first produced and understand the cultural political world that existed during that time.

This work will only review the small sample of shows within Sondheim's catalog. The study of all his shows could produce other results that may not necessarily concur with this thesis. Furthermore, Sondheim (while important) is not the only musical theatre composer and lyrist that deserves attention. I am limiting myself to one individual in the American Musical's history — and so my results will be specific to Sondheim and his direct connection to the 
American Musical and may not necessarily take into consideration other artists that might have come before or after him.

\section{Literature Review}

Despite being a newer art form then stage plays, recent decades have shown an increase in scholarly study of the American Musical. Instrumental comprehensive knowledge can be found in Showtime: A History of the Broadway Musical Theater (2010) by Larry Stempel and Broadway: The American Musical (2004) by Michael Kantor and Laurence Maslon. These provide a great overview of the American Musical from its founding to modern day. It is important to note that while these books mention and discuss critical elements relating to gender and sexuality, that is not the sole purpose of these books. Therefore, there are critical elements of feminist and queer theory that are left out of these books that require further research. The Oxford Companion to the American Musical (2008) by Thomas Hischak helps to provide an encyclopedia of important works, creators, and artists that are key to the American Musical. Raymond Knapp's The American Musical and the Formation of National Identity (2005) and The American Musical and the Performance of Personal Identity (2006) help to explore how identities are developed, portrayed, and explored through the American Musical. Additionally, David Walsh and Len Platt explore this even more through their work: Musical Theatre and American Culture (2003) which explores how musical theatre became a unique American Art Form that would uniquely show the good and bad of American culture on stage. Newer collections of essays such as The Cambridge Companion to the Musical (2017) edited by William Everett and Paul Laird as well as The Oxford Handbook of The American Musical (2013) edited by Raymond Knapp, Mitchell Morris, and Stacy Wolf help to explore certain specific areas of interest within the American musical. These collections are especially important 
in essays exploring the musical theatre's dark history of racism, sexism, and homophobia while also celebrating the victory of shows that redefined the American Musical and ushered in a new era. These works are crucial for reviewing multiple different perspectives on what the American musical was, is, and could be. Finally, Millie Taylor \& Dominic Symond's Studying Musical Theatre: Theory and Practice (2014) is a blueprint on musical theatre theory and how to analyze musical works, with chapters specifically focusing on sexuality, feminism, and identities.

Recent studies have focused on feminism and its impact on theatre and the American Musical. Theatre and Feminism (2015) by Kim Solga, Feminism and Theatre (1988) by SueEllen Case, and An Introduction to Feminism and Theatre (1994) by Elaine Aston help to provide readers with a basic framework that introduces feminist theories and then showcases how to apply those theories to theatre. In the end, the work provides readers a toolkit to apply feminist lenses when completing script and character analysis. Other works such as Changed for Good: A Feminist History of the Broadway Musical (2011) by Stacy Wolf go one step further than the history books that were described above, and instead looks at the Broadway Musical from a feminist lens. Due to the American Musical being a relatively heterogendered institution, it is well documented that the American Musical has historically been (and still is) filled with sexism. In recent years, more allegations of sexism and sexual harassment have made its way to the forefront of the headlines in the years following the \#MeToo movement. Wolf's work is especially important in understanding the history of musical theatre from a voice that has been historically underrepresented in typical musical theatre history books. Whereas Changed for Good provides a comprehensive feminist history of the American Musical, Wolf's other work, $A$ Problem Like Maria: Gender and Sexuality in the American Musical, (2002) focuses specifically on works from the 1950's-1960's. This work, which was one of the first feminist studies of the 
American Musical, helps to showcase how certain musicals from this period showcased strong female characters that went against the gender norms of that decade. As a result, she argues that the actresses created character personas that resonated with groups that had not been reflected in the American musical before, while also still appealing to the standard Broadway audience. Gender identity and the performance of gender has also been a recent area of scholarly study. Sex, Drag, and Male Roles: Investigating Gender as Performance (2010) by Diane Torr and Stephen Bottoms, and Staging Masculinities: History, Gender, Performance (2002) by Michael Mangan explores how gender identity and masculinity/femininity is expressed and performed. While these works are not written focusing solely on the American musical, they are important for my study. Rather, some knowledge on the theories of how gender and masculinity have historically been expressed and performed both on and off the stage, it allows me to use those theories to deconstruct the white, male centered history of the American Musical as well as when completing script and character analysis.

Another important area related to my study revolves around theatre and sexuality. Just as the American Musical has historically been plagued with sexism and racism, it has also been plagued with homophobia. As such, traditional narratives of American Musical history, as well as traditional analysis of the American Musical often leave out the LGBTQ+ narrative. John Clum's Something for the Boys: Musical Theater and Gay Culture (1999) is an instrumental work for my study. Like Wolf who provides a feminist history of the American Musical, Clum helps to provide a queer history of the American Musical. As such, while Clum recognizes that the American musical has historically been rooted in homophobia, he also notes that is has also been rooted in, and plays an important role in, gay culture. Clum devotes an entire chapter to Stephen Sondheim, who he argues has always provided mixed messages within his show. Clum 
argues that while Sondheim has never written about gayness, his shows can often be read through a gay lens. For Clum, aspects of Sondheim's work have always been intrinsically gay. To fully understand Clum's stance, as well as to further understand Queer theory in musical theatre, an understanding of theory surrounding sexuality is crucial. Michael Foucault's, $A$ History of Sexuality (1976) is central to understanding basic theory and concepts relating to sexuality and upon which queer theory builds on. Sarah Taylor Ellis uses Foucault's work as she explores queer temporalities in musical theatre through her essays and upcoming book: Doing the Time Warp: Queer Temporalities and Musical Theatre (2021). Many of the above scholars' arguments help lead us to think of many of Sondheim's characters as being the "other" --or an outsider to mainstream society. Jim Lovensheimer furthers this thought through his essay "Stephen Sondheim and the Musical of the Outsider" in The Cambridge Companion to the Musical (2008). Using Sondheim's own admission that he himself had felt as an outsider to mainstream society, Lovensheimer uses this to deconstruct various Sondheim works and helps to explore Sondheim's fascination of the outsider.

The literature on Stephen Sondheim and his career is immense, and despite this, there is still room for more scholarly research to be done. Biographies such as Stephen Sondheim: A Life (2011) by Meryle Secreast, helps to provide us an overview of Sondheim's life. This work is especially important as it gives us a look into Sondheim's upbringing and the relationship with his parental figures. This inside look could prove to be significant when analyzing his work in later chapters of my thesis. Other biographical work such as Sondheim (1993) by Martin Gottfried and Sondheim \& Co. (1974) by Craig Zadan also are crucial to the successful understanding of Sondheim's life. Joanne Gordons Art Isn't Easy: The Achievement of Stephen Sondheim (1990) and Stephen Banfield's Sondheim's Broadway Musicals (1993) detail more 
specifically on Sondheim's work, and explores them in greater depth than the biographies doallowing for a richer analysis of the work which will be essential for later chapters in the thesis. Both Stephen Sondheim: A Casebook (1997) edited by Joanne Gordon and The Oxford Handbook of Sondheim Studies (2014) edited by Robert Gordon give critical essays that help to explore Sondheim and his work using feminism and queer perspectives and theory.

\section{Methodologies}

The methodology involved in my thesis will include historical and textual analysis, along with an application of feminist and queer theory. The historical analysis will occur in chapter one, when I discuss the American musical and Stephen Sondheim's background, as well as in later chapters when I discuss the history of selected Sondheim works in relationship to the time that they had been written and originally performed. Literary analysis will occur through the deconstruction of various Sondheim works including Gypsy, A Little Night Music, Into the Woods, Company, Sweeney Todd, and Road Show.

\section{Chapter Overview}

Chapter one began with the problem and its background which will include a detailed statement of the problem, background, limitations of the study, justification of the study, significance of the study, review of the literature, methodologies, and a chapter review. In the background portion of this chapter, an overview and brief synopsis of Sondheim and the American musical theatre will be written which will serve as background information that the following chapters will build on.

Chapter two will focus specifically on Sondheim and Gender, along with a connection between theatre and feminism. Using the information from chapter one, I will explore 
Sondheim's work through a feminist lens. The shows that will be explored in this chapter include Gypsy, A Little Night Music, and Into the Woods.

Chapter three will specifically focus on Sondheim and Sexuality as well as the connection between queer theory and theatre. Again, using information from chapter one, I will explore Sondheim's work through a queer lens. The shows that will be explored in this chapter include Company, Sweeney Todd: The Demon Barber of Fleet Street, and Road Show.

Finally, in chapter four, I will bring everything together by offering a summary, make some conclusions as well as give some recommendations for future research. 


\section{CHAPTER II: SONDHEIM THROUGH A FEMINIST LENS}

In her book Changed for Good: A Feminist History of The Broadway Musical, Author Stacy Wolf asserts:

The Broadway musical is a commercial, profit-seeking, artistic commodity, entertainment form, and cultural product that participates in a larger conversation about gender and sexuality. Because the musical is a mainstream form that needs to cater to middle-class audiences' desires and expectations, one might expect only escapist, pleasant, seemingly apolitical subjects and stereotypical representations of women, and sometimes this is the case. And yet, the musical also explores social issues of the day, including women's rights and changing roles in U.S. culture, sometimes directly and sometime obliquely. Whatever the subject, the Broadway musical venerates female performers and provides substantial roles for women (Wolf 12).

Stemming from the heels of the Civil Rights Movement, the accompanying decades of the 1960's, 70's, and 80's were a period of rapid growth, restlessness, and change within American Society. With Civil Rights still in turmoil despite the developments of legal protections, other social movements such as the Gay Rights Movement, the Chicano Movement, and the Feminist Movement helped to show that change needed to be made. One of the ways in which these movements had the most change could be looked at in American culture.

The "traditional" notion of the second wave feminism speaks directly to this. Unlike other feminist "waves" where focus might have been more focused on legal changes, this wave was focused on the inequity that was present in social norms. We started to see the change in viewing the woman not as someone who is a home maid, there to cook and clean for the man, 
but we began to see the encouragement of women making their own life choices becoming more mainstream. This change was shown in all aspects of American culture. From new magazines such as Ms. to popular-culture icons such as The Mary Tyler Moore show and Aretha Franklin, they presented ideas that once seemed radical were becoming more mainstream. In Changed for Good, Wolf discusses one of the side effects that this change had, particularly in advertising. She states that "Until 1969, print ads geared toward women typically featured a woman selecting a product to please her boyfriend, but in 1970, Madison Avenue's strategy shifted and virtually every ad showed a woman making a choice for herself" (Wolf 95). Wolf would conclude that "Once feminism made it to Madison Avenue, it could surely make it to Broadway" (Wolf 95). In this chapter, I will argue how three of Sondheim's works, Gypsy, A Little Night Music, and Into the Woods, are political theatre with respects to women's rights. Each of these works showcases strong lead female character(s) who helped to emulate and illuminate women's fight for change. Whether in the workplace, in the bedroom, or in the home, Sondheim's shows critique societal and cultural stereotypes and norms that existed for women and instead advocated for women's advancements and liberties. While Sondheim might have incorporated some stereotypical behaviors, as some scholars might suggest, I argue that this was done to critique those stereotypes and advocate for a more liberal look at what women are and could be. Through these works, Sondheim helps us explore the notion of: 'What does it mean to be a woman in America?'

\section{Gypsy}

The 1950's were a shifting time in American culture. According to the US House of Representatives Office of History, Art, \& Archives, "Postwar prosperity made the banalities of housework less taxing but often came at a cost to women who gave up careers to maintain the 
domestic sphere. This lifestyle stressed the importance of a one-income household; the husband worked and the wife stayed home to raise the children" (History 1). It was also during this time in which the shift and focus on a "traditional family structure" became mainstream and prevalent in the US, and was reenforced by mass entertainment, advertisements, and mainstream media. This traditional family structure, in which a woman would marry a husband early on, give birth to children, and have a large family often alienated woman from their aspirations and dreams. Deviation from this structure or failing to give in to these norms would often cast one as an outsider, and the thought of negative repercussions would fill the minds. While Sondheim only wrote the lyrics for Gypsy, it nevertheless is an important work to look at. In Maddie McClouskey's article “In praise of women: Are Sondheim's musicals feminist?" In The Sondheim Review, she attributes the importance of the work to how "Sondheim's representation of diverse mothers and unorthodox family structures challenge gender roles as they relate to families" (McClouskey 17). Many women in Sondheim's shows feature diverse and even uncommon family structures, and the decision to put the story of a "...stiving, middle-class, single mother..." (McClouskey 17) on stage helps to show the commentary that Sondheim was making on the 1950's expectations of women.

Gypsy is a show that centers around sisters Gypsy (Louise) and June with their mom, Rose, with Rose having a never-ending push and desire for June to become a vaudeville star. Opening on Broadway in 1959, the show had a profound impact on how women could be featured on stage and what stories could be told. While there have been attempts to categorize Mama Rose as a 'monster' for what she made her children go through, one can also look at her as a character who had unrelenting love for her children and a desire for them to succeed. As Laurie Winer writes in her 1989 article "Why Sondheim's Women are Different" in The New 
York Times, "Rose...stood out in the musical landscape as a woman who insists on something new for herself and for her children. Even if she drives everyone she loves away, Rose does offer her daughters a dream of something other than the domestic safety of marriage" (Winer H1). More importantly for this analysis, while flawed, Mama Rose can be celebrated as a feisty feminist that fights against societal standards and norms that are presented to her by society and male dominating figures, such as her father and theatre managers. At the very least, the character of Mama Rose can be attributed to the flood gate opening for the plethora of strong female characters that came out following Gypsy.

In Act I, the song "Some People" helps early on to illustrate how Rose's character would be different than the women who had come before her and bent to society's standards. Rose states in Act I, Scene II:

ROSE. Anybody that stays home is dead! If I die, it won't be from sittin'! It'll be from fighting to get up and get out!

Some people can get a thrill

Knitting sweaters and sitting still-

That's okay for some people

Who don't know they're alive.

Some people can thrive and bloom, Living life in a living room.

That's perfect for some people

Of one hundred and give! 


\section{But I}

At least gotta try.

When I think of

All the sights that I gotta see yet,

All the places I gotta play,

All the things that I gotta be yet,

Come on, Poppa, whaddaya say? (Laurents 265)

In this song, we can see Rose fighting against not only the wishes of the patriarch, her father, but also the standards of the standard housewife. In it, she rejects the notion of the living room, and instead yearns for the sights, places, and things that she wants to see-her dreams and ambitions that are yet to be fulfilled. These lyrics are especially important for Rose becoming a feminist icon. This viewpoint is shared in Momma's Gotta' Let Go: A Character-Driven Analysis of the Mother Archetype in Musical Theatre, through which Richard Oakman details this connection of the lyrics to those sentiments from the turn-of-the-century suffrage movement by stating: "Not only are these visceral images attached, but Rose is also defending her decisions against her father, a man who is firmly rooted in the nineteenth century idioms of housewife and domesticated women. Rose is demonstrating the importance of female volition and pursuing achievement above conformity" (Oakman 56).

In an unconventional move for the time in which it was written, Gypsy plays with gender roles and relationships which helps to 'flip the script' in this world. This can be seen clearly through the relationship between Rose and Herbie at several crucial points throughout the show. Whereas Rose is a more dominant, always on the move, not wanting to settle down, Herbie on the other is more subdued, submissive, and wanting to settle down and have a family. Most 
importantly, he is not always wanting to run after the next great thing, whereas Rose does. Obviously, Rose portrays the personality that is, at the time, often given to males, while Herbie portrays the personality that is often assigned to women. This unique relationship with these flipped gender roles can be seen building upon one another as the show progress. We begin to see these flipped roles in Act I, Scene 9, when Rose and Herbie are talking to Cratchitt in the office. Early in this scene, Rose and Herbie come in to discuss with Mr. Grantziger that they believe that the contract was wrong. While they were auditioning for the Grantziger's Palace, the contract that they were given was for Grantziger's Variety. When trying to talk to Mr.

Grantziger, it is Rose who dominates the conversation, in which Herbie is consistently silenced and in the submissive position. This is shown through the lines:

ROSE. But June is the act! How is it supposed to go on without her?

HERBIE. Rose, we could-

ROSE (to CRATCHITT). How are Louise and I supposed to live?

ROSE. Take a good look at this person!

HERBIE. Rose-

ROSE. They're so smart in New York!

ROSE. New York is the center of New York! There's a whole country full of people who know people!-who know what a mother means to her daughter! It's hicks like you who don't know! And you want to know something else? Grantziger's a hick! He'll get no place!

HERBIE. Rose- 
ROSE. He's trying to take my bay away from me, that's what he's trying to do! Well, over my dead body, he will! (Laurents 292)

While some could attribute that this is the stereotypical attribution to women being over-reactive and hysterical, I instead would argue that this shows the flipped gender role. Despite Herbie trying to interject, Rose does not allow him to say much, dominating the conversation, addressing the problems, and continuing to propel the issue at hand forward. This is very uncommon for women at the time, who were expected to take a back seat in these situations, just as Herbie did. The culmination of these flipped roles and flipped desires come in Act II, Scene 4. At the beginning of the scene, the typical pre-excitement wedding jitters and planning is clearly given to Herbie. The scene begins:

HERBIE (to ROSE). Why aren't you nervous? I've never been so nervous in my whole life!

LOUIS (hands ROSE a baton). You've never been married before.

HERBIE. Well, your mother's never been married like she's going to be this time. For keeps and forever- to me! Ain’t you a little nervous, honey!

ROSE. Sure.

LOUISE. She's a little sad, too. About the girls.

HERBIE (admiring the marriage license): Say, the minister doesn't keep this, does he? I want to have it framed. Framed and hanging in our living room.

LOUISE (holding the COW head). What about this Momma?

ROSE. Take it.

HERBIE. Rose- 
LOUISE (putting the COW head on the suitcase). We can hang her up in the living room, too, Herbie. Over the mantelpiece.

HERBIE. Rose honey, it ain't that I don't know what you're feeling. Or that I don't know I oughta shut up. But I'm so goddam happy, I can't!

I'm finally getting everything I wanted! Evan a fancy ceremony with bridesmaids. Of course, what the minister's going to say when he gets a load of all that hair, I don't know. But the hell with him!

(ROSE's attention shifts to the hall.)

All he's gotta say is, Do you, Rose, take him Herbie? (Laurents 323).

His focus on the wedding certificate, the ceremony with bridesmaids, envisioning the living room in their house upon settling takes on a feminine approach. Rose takes a more masculine approach, and does not even seem to care, despite in earlier scenes agreeing that she would like to marry Herbie once the show at the theatre was over. Rose's inability to commit to Herbie, and reluctance to settle down and have a traditional household and life ultimately drives Herbie away. Later in Act I, Scene 4, once Rose has Louise fill in for the Star Act, Herbie leaves Rose. Herbie had left and while Louise is getting ready and putting on the dress, he comes back in and tells Rose his decision.

HERBIE. That's why I'm leaving.

ROSE. I apologize.

HERBIE. No, let me. For my resemblance to a mouse. No to a worm - the way I've crawled after you. No more, Rose. I won't. I was even going to crawl 
away from you - because my stomach started to turn over at the idea of coming back and telling you we're finished.

ROSE. Tell me tomorrow-after we're married.

HERBIE. We're never getting married, Rose.

ROSE. We certainly are! First thing in the morning, we'll-

HERBIE. Never, Rose. Not if you went down on your knees and begged. I still love you — but all the vows from here to doomsday...they couldn't make you a wife. I want a wife, Rose. I'm going to be a man if it kills me.

ROSE. Herbie... why does everybody walk out?

HERBIE. Maybe Louise won't. (He pats her shoulder. Without looking up, she reaches for his hand and holds it there.)

ROSE. Don't leave, Herbie...I need you.

HERBIE. ... What for?

ROSE. A million things.

HERBIE. Just one would be better. Good-bye, honey. (Silence. He kisses the top of her head.) Be a good girl. (Quietly, he goes out the door. Music Starts.). (Laurents 326).

What is especially poignant in this scene is Herbie's speech when he compares himself to a worm and his literal depiction that he has crawled after Rose. This again puts Herbie in a role that is often defined by society as feminine. Instead of a woman chasing after a man, it is instead a man chasing after a woman — unable to leave because of a sense of dependency that exists. For Herbie, he states that his stomach started to churn, and he got physically sick at the thought of 
having to tell Rose he is leaving, often how women often think that they must be dependent on the males and often are unable to bring themselves to leaving situations, even if they are in toxic situations.

If "Some People" is the beginning of the story for Rose's character development and functions as her 'I want' song, then the 11 o'clock number, or the climax of Rose's character development can be found in "Rose's Turn" in Act II. If one still thought that Rose was a monster, this was Sondheim's and his collaborator's one last chance to argue against this. This is one of the first times in which we see Rose remove her façade and allow us to look at her pain, frustrations, and what her passions were that drove her to see why she did what she did. In many ways, it provides audiences a somewhat sympathetic, renewed look at this person who had constantly had a brick wall up — not allowing anyone including her father, Herbie, or her daughters - to break it. It finally crumbles down and out flows all this emotion and energy that she had been hiding. Much of this is that while she did everything for her children to succeed, there was also a wanting for Rose, herself to also succeed. Just as her daughters would receive spotlight, Rose too longed for that spotlight. In the song she sings:

ROSE. Why did I do it?

What did it get me?

Scrapbooks full of me in the background.

Give 'em love and what does it get you?

What does it get you?

One quick look as each of 'em leaves you.

All your life and what does it get you?

Thanks a lot—and out with the garbage. 
They take bows and you're battin' zero

I had a dream-

Well, someone tell me, when is it my turn?

Don't I get a dream for myself?

Startin' now it's gonna be my turn!

Gangway, world,

Get offa my runway!

Startin' now I bat a thousand.

This time, boys, I'm takin' the bows and

Everything's coming up Rose-

FOR ME! (Laurents 337).

This ability for Rose to let out her feelings and talk about her emotions is powerful in giving Rose agency. Whereas women at the time were typically told to repress their feelings and not let them show (at risk of being labeled hysterical), the show allows Rose to fully explore these. This helps lead to a catharsis moment for Rose before leading into the final scene in which Louise and Rose resolve their differences and go with their dreams to become Madam Rose and Her Daughter, Gypsy!

One cannot look past the powerful element of Gypsy is its' comment on theatre itself. Just as the show is focused on the "source material in Gypsy Rose Lee's memoir which accounts for Rose's adversity in the face of the male dominated institution of theatre which she was trying to assimilate herself into" (Oakman 55). This can also be the struggle for women within the world 
of theatre as well. At theatres of all sizes, Rose fights against the male dominance that exists, whether that is small in scale (such as Uncle Jocko vaudeville theatre) to large in scale (such as Mr. Grantziger's Palace). In each one of these, we see Rose having to fight against and overcome the male dominance in these spaces. As discussed in the introduction, the theatre is still an overwhelming male industry, and women are still vastly outnumbered in pivotal roles of the creative process. A contemporary look at Gypsy helps to illustrate how far, and yet so little theatre has come with regards to woman's success in this field. This notion can be seen throughout the show with the different theatre venues, however, is most notably seen in Act I during the time at Mr. Grantziger's theatre. In Act I, Scene 9, we see that Mr. Grantziger wants to take control of June's career. For him, he sees potential for June to be a successful actress. As a result, he wants to invest in June's career-giving her the resources and tools to be a great actress. In the scene, we learn this through Cratchitt. She states:

CRATCHITT. Look, friend. Strictly between us, if I were you I'd sign that contract. There's only one item in that act of yours that the Boss likes: Dainty Little June. He thinks she can be an actress.

ROSE (as JUNE stands up): He's right.

CRATCHITT. Can be-if.

HERBIE. If what?

CRATCHITT. If she goes to school for a solid year and takes lessons. He's ready to pay for everything - on one condition. (To ROSE.) You stay away.

ROSE. Stay away? I'm her mother!

CRATCHITT. You said it, I didn't. (Laurents 291). 
While we do not often see Rose wanting to settle down with a family as much as Herbie does, this is a time when she argues for it-against Mr. Grantziger taking her daughter June away, in which it would be separating a daughter from her mother and breaking up the family. In many ways this goes against what Rose has been wanting. Stardom for June is something that Rose has wanted for June, but only if she is with her. Otherwise, she does not want June to achieve this and instead live a life that Rose had rebelled against in "Some Body". This connection can be seen in their Farm Boys audition for Mr. Grantziger where June refuses the stardom she would receive on Broadway, and instead stayed back on the farm, despite being a life that Rose had previously rejected.

One final important point that needs to be discussed when looking at Gypsy with a feminist lens is how the show deals with the burlesque and stripping. Initially, the show seems like it would take a conservative view on the subject. One such example is when Rose refers to it as "Filth" and this notion that if one would engage in a burlesque performance venue, any chances of returning to traditional vaudeville would be over. This would align with both thinking then and contemporary viewpoints that burlesque, stripping, and the like were "dirty" activities - one that was not reputable. It was not what "good women" did and was only done by those who were already the "others" in society. In an article in Little Village Magazine titled “The intersection of burlesque and feminism", burlesque performers Auralie Wilde and Hugh Jindapants, along with Patrick Dolan who is a Gender, Women's and Sexuality Studies Professor from the University of Iowa discuss this divide of how burlesque is seen by many (including feminists) as performers "... adopting a historically oppressive form, women are complicit in reinforcing an objectifying institution" (Taft 1). The performers and scholar, however, suggest that performers are instead “...reclaiming a genre of expression that was historically controlled 
by men, burlesque performers are able to take back control of their own sexuality" (Taft 1). In the case of Gypsy, this is the philosophy and viewpoint that is shared by many of the performers. One of the first signs can be seen through the song "You Gotta Get a Gimmick" sung by Mazeppa, Electra, and Tessie. In this song, Sondheim and his collaborators began to give those who engaged in stripping agency and helped to show that they were, in fact, not as dirty as society often thought of them. However, the biggest and most important element comes in Act 2, Scene 5 when Louise and Rose argue in Louise's dressing room. Despite Rose's negative outlook at burlesque, Louise has risen to a star and has finally been able to be herself—not something that her mother wanted her to be. Louise explores:

LOUISE: I SAID TURN IT OFF! Nobody laughs at me—because I laugh first! At me! ME—From Seattle; me—with no education; me, with no talent—as you've kept reminding me my whole life. Look at me now: a star! Look how I live! Look at my friends! Look where I'm going! I'm not staying in burlesque. I'm moving — maybe up, maybe down—but wherever it is, I'm enjoying it! I'm having the time of my life because for the first time, it is my life! I love it! I love every second of it and I'll be damned if you're going to take it away from me! I am Gypsy Rose Lee! I love her-and if you don't, you can clear out now! (Laurents 332).

Louise has found freedom and is no longer a kid controlled by her mom Rose, no matter how much Rose wants to remain in control. For Louise, she is her own person-someone who has agency to decide how she lives and who she wants to be. More importantly-Louise can finally love herself — doing something that she enjoys, without regard for what society or her mother thinks - because that is not what is important. Through this, Gypsy gives us a poignant 
coming of age story. Louise can be her own person and can decide how she wants to live her life. Like her sister, June, she is able to break away from the control of her mother and is able to take control of her actions and decisions. At the same time, Gypsy is also a coming-of-age story for Rose. Rose at the end is finally free to let herself express her own feelings. She is no longer bonded by how society dictates she should act and is free to be herself and to finally live life in a way that supports her and not others.

\section{A Little Night Music}

Sondheim's 1973 Broadway show, A Little Night Music, is a feminist's dream. Not only does this production showcase a diverse family structure like Gypsy, women who have sexpositive expressions are also represented. By having both female leads be two generations of single mothers, A Little Night Music features unconventional family types. Maddie McClouskey asserts in her essay "In Praise of Women", that "Women have varying traits and behaviors, which are well represented in the Sondheim canon. This diversity is paramount, because it tells audiences that there are many legitimate female lives to be led. Sondheim's body of work follows this theme in how these diverse female characters feel and act in a more taboo arena: sex" (McClouskey 17). The 1960's was the decade of the sexual revolution in which the sexual liberation movement challenged the traditional norms surrounding sex and sexuality in our culture. From PBS Women in American History Collection from the "American Experience" series, they state that "At the core of the sexual revolution was the concept -- radical at the time -

- that women, just like men, enjoyed sex and had sexual needs. Feminists asserted that single women had the same sexual desires and should have the same sexual freedoms as everyone else in society. For feminists, the sexual revolution was about female sexual empowerment" (PBS 1). Like so many Sondheim shows that comment on the social and political movements and shifts of 
their time, A Little Night Music is a shining example of this era in the way that it empowers Petra by allowing her to engage in “...sexual expression rather than imprisoned by it” (McClouskey 17).

Susan Speidel agrees with this Sondheim work and its' uncanny connection to female empowerment. In her essay "Extraordinary women: Desiree, Petra and Madame Armfeldt defy expectations in Night Music" in The Sondheim Review, Speidel argues that:

Like Madame Armfeldt and Desiree, Petra deals frankly and pragmatically with sex. The difference is that she pursues it for fun, not for money. She thinks and acts unconventionally for a woman of her day, approaching the act more like a man than a woman of the time. She is the aggressor, seducing both Henrik and Frid, and she speaks frankly and openly about her romantic adventures. (Speidel 30).

Many feminists point to the song “The Miller's Son” in Act II, Scene 7, as a clearly defining moment for Petra's expression. During this song Petra sings about three different imaginary futures with different husbands: the miller's son, the businessman, and the Prince of Wales. Petra really does leave little to the imagination. For example, when talking about the Prince of Wales, Petra explores:

Meanwhile...

It's a rip in the bustle

And a rustle in the hay

And I'll pitch the quick fantastic,

With flings of confetti

And my petticoats away up high. 
It's a very short way

From the fling that's for fun

To the thigh pressing under the table.

And a person should celebrate everything

Passing by.

And I shall marry the miller's son.

(She smiles, as the lights fade on her). (Sondheim, "A Little Night Music"

160).

Petra's sex-positivity can be linked to her own understanding that sex is to be celebrated — not only strictly for marriage or procreation as society has often dictated. It is something to be celebrated, explored, and a source of curiosity. Petra's character is important for Broadway. As McClouskey states: “In a culture in which we condone men's lewd over-sharing in the proverbial locker room, it can be easy to forget that women like having sex just as much as men do. Sexpositive characters such as Petra act as a reminder that the sexes are equal in the bedroom as well as the home and the workplace" (McClouskey 17).

On the opposite side of the social spectrum, we have Madame Armfeldt. She too was a very sexual being, but unlike Petra who often engaged in it for pure fun, Madame Armfeldt often engaged with it to help her build security and stability—financial stability — for herself and her family. In other words, she made sure that she had the resources that she needed to be a single mother and her story runs contrary of the notion of the woman being dependent on the man. This very notion is prevalent in Act 1 , Scene 4 when she sings "Liaisons". She states:

Too many people muddle sex with mere desire, 
And when emotion intervenes,

The nets descend.

It should on no account perplex, or worse, inspire.

It's but a pleasurable means

To a measurable end.

Why does no one comprehend?

Let us hope this lunacy is just a trend. (Sondheim, "A Little Night Music”, 68).

In the song, Madame Armfeldt sings and mocks what modern lovers think about relationships and believes that they are the ones that need to change. She continues to talk about the 'measurable ends' throughout the songs by recounting about three former lovers that she has had sexual encounters with: the Baron De Signac, the Duke of Ferrara, and the King of the Belgians and recounts about the times. In each of these stanzas, she describes how she acquired something from each. She sings:

MADAME ARMFELDT. At the villa of the Baron de Signac,

Where I spent a somewhat infamous year,

At the villa of the Baron de Signac

I had ladies in attendance fire-opal pendants

At the palace of the Duke of Ferrara,

Who was prematurely deaf but a dear,

At the palace of the Duke of Ferrara

I acquired some position

Plus a tiny Titian... 
She would go on to explain that she also received even more:

I acquired a chateau

Extravagantly o-

Verstaffed

In the castle of the King of the Belgians,

We would visit through a false chiffonier.

In the castle of the King of the Belgians

Who, when things got rather touchy,

Deeded me a duchy... (Sondheim, "A Little Night Music”, 68).

Through each of these three encounters we see her gaining pendants, a place to live, and territory. While some might argue that this is her depending on the men, I would argue that she is not. Dependent on the men implies that she just sits there and waits for men to bring her thingsthat she does not have wants or desires and instead depends on what they think she needs or wants or desires. Instead, through her actions_-she goes searching for these men and actively engages in obtaining things for her future. Historically, women have been seen as inferior or as commodities that were to be owned by the men. Arranged marriages are an example of thiswomen being given to other men like property to be owned. In this song, gender roles are being switched. Instead of women being used as property and material goods, it is instead men that are being reduced to this and being used by Madame Armfeldt. By doing this, she is taking agency in helping to define herself, but also build up the security and foundations that she will need for her life-whether it is with a man or not. These flipped gender roles can also be seen when 
Madame Armfeldt refers to these men in inferior ways, such as "Tiny Titans", which helps to flip the power dynamic.

Again, this show critiques the social expectation that women should marry, have children, and stay in the home. If by some reason they did work, it would be limited to certain "female" professions such as a teacher, servants, nurse, etc. Speidel notes that each of the main characters in the show are reluctant to give into these society's standards. She notes:

Alternatives to reputable career paths - mistresses, courtesans, actresses and so on - were strictly outside the realm of respectable society. However, the risk of scandal does not seem to deter the women of A Little Night Music. Madame Armfeldt and Desiree seem unaffected by any loss in reputation or social position, and Petra, who is respectable enough as a servant even though she spends her time off in promiscuous pursuits, is ardently unconcerned with what anyone will say. All three present a stark contrast to the romantically stagnated, maledependent characters of Anne and Charlotte. (Speidel 29).

Like Sondheim did with Gypsy and would later repeat in Into the Woods, Sondheim critiques the dependency, or the notion of dependency, that society often has of women depending on the male in the relationship. In Act I, Scene 1, Madame Armfeldt and Desiree engage in the song "The Glamorous Life" in which they reconcile with the fact that they do not live up to society's standards. For the mother who does not live up to the standards, Fredrika sings:

Ordinary mothers lead ordinary lives:

Keep the house and sweep the parlor,

Cook the meals and look exhausted.

Ordinary mothers, like ordinary wives, 
Fry the eggs and dry the sheets and

Try to deal with facts.

Mine acts. (Sondheim, "A Little Night Music" 35).

To the daughter who does not live up to expectations, Madame Armfeldt sings:

Ordinary daughters ameliorate their lot,

Use their charms and choose their futures,

Breed their children, heed their mothers.

Ordinary daughters, which mine, I fear, is not,

Tend each asset, spend it wisely

While it still endures...

Mine tours. (Sondheim, "A Little Night Music" 37).

The importance of the song is that while they do not live up to the standards that society has put up, they are still "relatively prosperous and well adjusted" (McClouskey 17) even without men in their life. This lack of dependency is crucial and a central theme in feminist thought- that a woman should not be limited or defined by their dependency on a man, but by their own character and ability. By portraying these characters in this light, he is critiquing the societal standard that has often come to describe a woman in relationship to her man—as separate but nonequal beings.

As discussed above, Desiree is an interesting character in the show. When we first meet her, Desiree is working in the theatre. In many cases, Desiree is doing what would have been the unconventional route - not married, an actress, etc. This is often a source of the confrontations 
that she has with her own mother, who calls her a fool "who know too little" (Sondheim, "A Little Night Music” 16). It even leads to her mother taking Desiree's daughter, Fredrika, to live with her in the country. But how the character progresses through the show helps to muddy the waters on whether she remains an independent woman, or whether she conforms back into societies standards of proper behavior for a woman. This can be clearly seen in Act I, Scene 4 as well as later in Act II.

In Act I, while at her place we begin to see this play out by her giving into Fredrik, an old lover, by offering to do things sexual to aid an old friend. Where this differs from Madame Armfeldt is that Desiree and Fredrik have a past - a history. We begin to see both start to struggle with this history and attempt to not admit that this is a rekindling of a fire of some sort. The culmination of this is found in Act II, Scene 8 after the Russian roulette game between CarlMagnus and Fredrik. It is after this that Fredrik finally professes his love for Desiree and confesses that Fredrika is his daughter. In the reprise of "Send in the Clowns", Fredrik states:

FREDRIK. How unlikely life is! To lose one's son, one's wife, and practically one's life within an hour and yet to feel—relieved. Relieved, and, what's more, considerably less ancient. (He Jumps up on the bench)

Aha! Desiree!

DESIREE. Poor Fredrik!

FREDRIK. No, no, no. We will banish "poor” from our vocabulary and replace it with "coherent."

DESIREE. (Blank) Coherent? 
FREDRIK. Don't you remember your manifesto in the bedroom? A coherent existence after so many years of muddle? You and me, and of course, Fredrika?

(They kiss. The music swells).

FREDRIK. (Sings) Make way for the clowns.

DESIREE. (Sings) Applause for the clowns.

BOTH. They're finally here. (Sondheim, “A Little Night Music" 172).

Ultimately, Fredrik and Desiree both get what they have been yearning for. Fredrik has found his true love, and Desiree has found hers — and the ability to start a family, settle down, and leave the theatre. While many have pointed to this as Desiree succumbing to the traditional notions of gender roles (starting a family, etc.), I would argue that she did not succumb simply to traditional standards, and instead, found true love. She was not forced by society or by society's will to elope with Fredrik. Nor was she forced to by her mother. One of the reasons why Desiree was in the theatre was to make a statement against the conformity that was expected of her as a woman. She made her statement. For Desiree, she did not just want to leave the theatre and find a husband how society or her mother may have wanted, or how "ordinary mothers/daughters should operate", but instead, wanted to find what she wanted, what she yearned for and when the time was right for her. However, it was due to their confession of true love- that they found what both were yearning for. Desiree consented to this lifestyle—-she continued to have agency for herself, her desires, and wants—still making her a strong female character in a traditional setting. 


\section{Into the Woods}

Despite being towards the end of the eras in which modern social movements were existing, Into the Woods is a prime example of Sondheim creating strong female characters who showcase feminist traits or showcased new cultural norms that had been becoming more mainstream following the feminist movement. Collaborating with James Lapine, Into the Woods debuted on Broadway in November of 1987. The show intertwines the stories of classic fairy tales, such as Rapunzel, Jack and the Beanstalk, Little Red Riding Hood, and Cinderella with the story of the Baker and his wife as they attempt to begin the chance to start a family. While Act I is essentially a retelling of the initial stories up to the "Happily Ever After", Act II focuses on what comes after the "Happily Ever After". While this show does have its flaws when it comes to feminist ideals (the most jarring being the witch and her desire for beauty), many of the central female characters of the show are strikingly feminist for the time. The characters who I wish to focus on include: The Baker's Wife, Cinderella, and Little Red Riding Hood.

The Baker's wife is an intriguing character. Whereas some of the characters in the show only tend to show feminist traits in the second half after the "Happily Ever After", the Baker's wife rallies against gender norms through the entire show. One of the things that sets this character apart from female depictions of the time is how much thought this character can have, and how she is in many scenes, the voice of reason for the man. Traditional portrayals of women during this time would be the opposite in which the man would be the voice of reason. The woman would depend on the man. Sondheim flips the script and instead has the baker rely on his wife far more then she must rely on her husband. Additionally, the wife does not play into the thought that the woman should just stay home. While the baker tries his hardest to have his wife stay home, she refuses, and the two share a duet that is appropriately titled "It Takes Two". This 
song helps to reinforce the importance and the significance of the wife to the baker and allows her to be more than just a housewife. Despite these instances in the first act of the baker's wife portraying revolutionary feminist traits, the biggest comes in act II when she and the prince have an encounter in the Woods. This, to no surprise, has caused controversy among scholars, especially after the fact that she dies while the prince does not.

While many feminists have argued that the death of the baker's wife was in response for infidelity (the typical point of the wife/woman getting the punishment while the man goes unpunished), I would argue that looking at the musical through an intersectional and poststructuralist lens could come to a different conclusion. Before the death of the baker's wife, and after her romance with the prince, she performs 'Moments in the Woods'. This piece, which follows directly after the prince leaves allows us to focus instead on the true issue which causes the wife her demise. In her song, the baker's wife sings that:

Must it all be either less or more,

Either plain or grand?

Is it always "or"?

Is it never "and"?

That's what woods are for: (Sondheim, "Into the Woods" 112).

New interpretations from feminists, especially after the 2014 Disney film adaptation, are beginning to argue that the death is not a punishment, but a release from a society that is often too strict and dictated. In an article by Natalie Wilson, a literature and women's studies scholar at Cal State San Marcos in Ms. Magazine, she writes that "Indeed, this song espouses the "both/and" mantra of intersectional feminism: the belief that dichotomies are limiting and hierarchies a bore. It champions instead the notion that it does not have to be either/or but can be 
and as well as or" (Wilson 1). Wilson goes on to compare the baker's wife to that of similar themes in other works of American culture such as the novel The Awakening or Thelma \& Louise's ending. Sondheim seems to agree with this notion of a binary hierarchy. In his selfreflective work, Look, I Made A Hat (2011), Sondheim writes: “In an instant, the Wife's problem became the contemporary soap-opera dilemma: adventure versus dependability, romance versus fidelity" (Sondheim, "Look, I Made a Hat" 92). This struggle with this binary hierarchy, in which everything depends on one or the other and provides no room for fluidity which is something that many groups of individuals, in particular feminists and queer activists, have worked for so long to undo. These hierarchies are often built on heteronormative, male, schools of thought. Therefore, the death of the wife is not necessarily in punishment for her actions, but instead, it is a release from the rigid binary standards of society. Sondheim would continue to push the edges of gender norms and flip the script of heteronormativity when the Baker states "You don't understand. My wife was the one who really helped. I depended on her for everything" (Sondheim, "Into the Woods" 122). This again, allows for a revolutionary view of the man dependent on woman, instead of the woman dependent on the man.

Cinderella takes a rather feminist turn in the second act from how portrayals have been typically portrayed. However, even in the first act, Cinderella begins to flip the script on her story, in a way that gives her more agency. In Act I, Cinderella goes to the ball and leaves behind her glass slipper. While traditional versions have had the slipper accidentally left behind, Sondheim and Lapine give Cinderella agency by allowing her to make the decision to leave behind one of her slippers as a clue. Cinderella's overall goal was to see how the prince would respond. In her song "On the Steps of the Palace” Cinderella states that

Then from out of the blue, 
And without any guide,

You know what your decision is,

Which is not to decide.

You'll just leave him a clue:

For example, a shoe.

And then see what he'll do.

Now it's he and not you

Who is stuck with a shoe,

In a stew,

In the goo,

And you've learned something, too,

Something you never knew,

On the steps of the palace! (Sondheim, "Into the Woods" 64).

Sondheim himself has commented on Lapine's and his take of Cinderella and how the character has been previously portrayed. In Look, I Made a Hat Sondheim states that "Cinderella doesn't lose her slipper, she deliberately leaves it behind. She knows she's an imposter and doesn't want willingly to mislead the Prince (and the world). She figures that if the Prince really cares to see her again, he'll follow the clue she has left. She doesn't want an accident of fate to fix her life, she wants to be loved for herself" (Sondheim, "Look, I Made a Hat" 79). Sondheim also acknowledges that in virtually any other interpretation of Cinderella in over 500+ years, there is none (to his knowledge) that supports and gives agency to Cinderella like this. 
Sondheim and Lapine continue to give Cinderella agency through the second act. At the end of the first act, Cinderella and the Prince get married, she is now a princess, and the beginning of Act II showcases the multiple dilemmas that Cinderella faces. If one were solely looking at this part of the script, it would be hard for one to see this as a feminist piece. In "So Happy", Cinderella sings:

Princesses are good,

Princesses are nice.

Princesses must pay a price,

So just smile, Cinderella.

Style, Cinderella!

Nice good good nice...

Don't forget your place,

Don't be thought a fool,

Learn benevolence and grace.

Calm and cool, Cinderella.

Rule, Cinderella.

Nice good smile

Rule good nice... (Sondheim, "Look, I Made a Hat" 86).

In this song, we can clearly see how Cinderella is struggling between being herself and being the princess that people expect her to be. She spends time strategizing over what princesses are and what they are not and how one is expected to act. However, given the broader context of the full second act, this scene is integral of Cinderella's personal development. With this struggle, we 
can begin to see how non-conforming Cinderella wants to be. In Act I, she tried so hard to not give in and give people a false impression of who she was. She instead, put the ball in the prince's court. In Act II, we begin to see that Cinderella is struggling with whether she should conform to what society's concepts of what a princess should be. In this case, I would argue that Sondheim is using these stereotypes and gender norms to comment on the negativity of them, and not to support them.

However, the biggest support of Cinderella's self-agency comes towards the end of Act II, upon confronting the prince on his behavior.

Baby begins to calm down; Cinderella's Prince bounds onstage; he doesn't recognize Cinderella

CINDERELLA'S PRINCE. Hello. (He begins to cross the stage)

CINDERELLA. The giant went in that direction.

CINDERELLA'S PRINCE (realizing it is Cinderella). My darling. I did not recognize you. What are you doing in those old clothes? And with a child?

You must go back to the castle at once. There's a giant on the loose.

CINDERELLA. The giant has been to the castle.

CINDERELLA's PRINCE. No! Are you all right?

He moves to her; she nods and walks away.

My love. Why are you being so cold?

CINDERELLA. Maybe because I'm not your only love. Am I?

CINDERELLA'S PRINCE (Beat). I love you. Truly I do. (Pause) But yes, it's true.

CINDERELLA. Why, if you love me, would you have strayed? 
CINDERELLA'S PRINCE. I thought if you were mine, that I would never wish for more. And part of me is content and as happy as I've ever been. But there remains a part of me that continually needs more.

CINDERELLA. I have, on occasion, wanted more. But that doesn't mean I went in search of it. If this is how you behave as a prince, what kind of King will you be?

CINDERELLA'S PRINCE. I was raised to be charming, not sincere. I didn't ask to be born a King, and I am not perfect. I am only human.

CINDERELLA. I think you should go.

CINDERELLA'S PRINCE. Leave? But I do love you.

CINDERELLA. Consider that I have been lost. A victim to the giant.

CINDERELLA's PRINCE. Is that what you really wish?

CINDERELLA. My father's house was a nightmare. Your house was a dream. Now I want something in-between. Please go.

\section{He begins to exit.}

CINDERELLA'S PRINCE. I shall always love the maiden who ran away. CINDERELLA. and I the faraway Prince. (Sondheim, "Into the Woods" 128). Many feminists and scholars have pointed to this passage of being vitally important to recognizing and understanding Sondheim's and Lapine's version of Cinderella. For many, this shows Cinderella, as having control and agency in deciding her life and her future. Cinderella is not portrayed as the hysterical woman and is shown as being calm and collected while still making sure that she does not get suckered into doing what the prince wants. Anna Hendrick, who played Cinderella in the Disney film adaptation, states in an interview what makes 
Cinderella different in this version is that: "What's interesting about this version, and what's very modern about this one, is that not only does Cinderella leave her prince, but she leaves with forgiveness and respect and compassion for the prince. It's not black and white for her. It's not even black and white for the prince, who lives a pretty black-and-white life. There's a moment that's basically, "This isn't our path.” [Prince Charming says,] "I shall always love the maiden that ran away." [And Cinderella says,] "And I the faraway Prince." There is something extremely relevant and modern about the idea of civility in separation" (Patches 1). Other scholars have expanded upon this idea and stated that the simple fact that she left what she had, what was comfortable and expected of her, to find out what was more right for her is a big twist to traditional gender norms regarding the women being dependent on the husband, as well as the focus on marriage and the negative connotations of single/divorced life.

Little Red Riding Hood also allows us a chance to catch feminist glances through her character. Little Red Riding Hood is a lively source of discussion among feminists and reinterpretations and adaptations have consistently been made revolving around the character. This source of lively discussion is thanks to the story's semiotics, which as Laura Evans from the University of North Texas points out is ".... a tale of the well-intentioned, though slightly absentminded, Red and her seduction" (Evans 129). Once again with this character, Sondheim and Lapine break gender normality for the time, and allow for Little Red Riding Hood to take on a more feminist persona then traditional versions of the fairy tale have historically portrayed. Little Red Riding Hood's song “I Know Things Now”, allows for Little Red to begin to understand her place in the world and how she wants to interact with the world. Sondheim reflects in Look, I Made a Hat that Little Red's song is essentially her “...experience of learning” and that at the suggestion of Lapine's wife that the song, like others "...dealt with what the 
adventures meant to the adventurers rather than simply being narrative descriptions" (Sondheim,

"Look, I Made a Hat" 69). While many may point to the cat-calling that Little Red is subjected to by the Wolf, as Sondheim reinforcing that concept, I rather see it as Sondheim critiquing and pointing out the wicked nature. From the incident with the wolf, Little Red seems to embrace womanhood and uses it as a source of strength, not weakness. Particularly as the show progresses, Little Red shows strength on encountering the woods for herself, not relying on a man or a prince's interpretation or advice. As such, she is using her own thoughts and feelings to decide for herself rather than that of others who are deciding for her.

\section{Conclusion}

These three shows, while vastly different in plot, have a strand that binds them together. Each show critiques and advocates for what women's roles have been and can be. Whether those roles be in the workplace, in the bedroom, or in the home, each of these shows take a stand and rejects the outdated and sexist norms. Like the changes in culture, politics, and society, that occurred at the time; so, did Sondheim represent these shifts within his works. Many scholars are correct that Sondheim did use some heteronormative ideals within his shows. We can see this through the Baker's Wife in Into the Woods wanting a child, and examples of the women wanting to get married and start a family can be seen in many of his shows. However, the area where I differ from these scholars is that I do not view these elements as limiting the lives of the characters. Sondheim's strong female characters, such as the ones that we have discussed in this chapter, have agency and strength to direct their future. If one wants a family or wants to have a baby, it is through their own accord-not because it is their "duty" to society. This element of ownership is unique and positions Sondheim as a champion for incorporating feminist ideals in his work. Due to his inclusion of these elements, and his showcasing of ultimate success and 
advancement over ultimate failure, positions Sondheim as picking a side. Incorporating this with our definition of political theatre from my introduction, I argue that these works are indeed political. 


\section{CHAPTER III: SONDHEIM THROUGH A QUEER LENS}

In Jim Lovensheimer's essay "Stephen Sondheim and the Musical of the Outsider” in William Everetts and Paul Lairds The Cambridge Companion to the Musical, he takes note that pre-Carousel, the likelihood of having an outcast as a main character was rare; and that it was only post Carousel, especially in musicals by Sondheim, that we began to see an outsider as a principal figure. Lovensheimer states that:

...Sondheim's body of work for the musical theatre thus far suggests that his early emotional reaction to a work about a disenfranchised member of society, a nonconformist, was an indication of the theme upon which he since has written many variations, each of them in a distinct personal style. He seems always to have been attracted to characters whose actions place them outside mainstream society. (Lovensheimer 247)

In an interview with Frank Rich of The New York Times titled: "Conversations with Sondheim”, Sondheim seems to agree with this notion. Sondheim states, “...the outsider is basic to a lot of dramatic literature. This country's about conformity. And so nonconformity is a fairy common theme, and it's obviously something I feel, belonging to a number of minorities" (Rich 29). When asked if he feels being gay has anything to do with it, Sondheim responds with “Homosexuality, certainly it's a part of it...” (Rich 29). While Sondheim often dismisses those certain characters were written and intended to be gay, there have been numerous scholars who cannot help but make the connection between the Sondheim's shows and queer tendencies that present themselves in his work. Scholar Scott Stoddart in his essay "Queer Sondheim” in The Oxford Handbook of Sondheim Studies edited by Robert Gordon states: "Despite Stephen Sondheim's long silences and his veiled references to queerness throughout his work, the gay 
community embraces him as an artist who challenges the conventions of the Broadway musical, ensuring that the form still resonates with the youth of today. In dismantling the heteronormative structure of the traditional musical, Sondheim has "queered" the form, whether there are openly gay characters or not" (Stoddart 429).

Any first look at Sondheim shows would not seem to be directed towards any queer tendencies. In a more modern, diverse, and inclusive society, assassins, princes lusting over princesses, and a serial killer might not be the first things that come to mind when one thinks of someone being "queer". However, it is important to acknowledge that, while it might not have been direct, there is a long history in media in which homophobia was used to show those who identify as queer as evil, immoral, or dangerous folks. This history gives us the push needed to take a deeper look at characters through a different lens. Therefore, detailed readings of Sondheim are required to understand all the intricacies and subtle nuances of his work that help make his work into what many consider to be "gay theatre". Part of the trouble of understanding Sondheim through a queer lens is his reluctance to write gay and queer elements directly in his work. This, I would argue is the result of the time that he was writing. Sondheim's works were primarily written through the 1960 's-1980's, and these years were turbulent decades for Gay Rights. During some of the time that Sondheim had been writing, the Stonewall Riot had not yet occurred, and in many times, there were active laws against outwardly being LGBTQ. These led to the reluctance of many individuals to be "out"; let alone write or showcase direct gay scenes on the stage. While The Boys in the Band had been produced Off-Broadway in the 1960's, and there were many artists who were brave enough to be their authentic selves and open with their sexuality, these were much less common occurrences and were some of the only instances of open LGBTQ identity in the theatre community. Sondheim reflects on this when he sat down 
with Meryle Secrest for her biographical work on his life. In Secrest's Stephen Sondheim, A Life she recalls him stating:

I don't think I knew more than maybe four homosexuals in the fifties and sixties who were openly so. I'm guessing four. I'm actually thinking of one couple who were quite effeminate, so there was very little to conceal. I knew a lot of homosexuals who did not want it to be known. Everybody knew the theatre was full of homosexuals, but nobody admitted to being so. (Secrest 180).

Additionally, if we consider Stacy Wolf's account that theatre is a business, that could also help explain why Sondheim wrote his shows how he did. In Something for the Boys: Musical Theater and Gay Culture, author John Clum quotes Sondheim as saying "I had the idealistic notion, when I was twenty, that I was going into theater. I wasn't; I was going into show business, and I was a fool to think otherwise" (Clum 215). Clum's assertion of this point is that Sondheim, to be successful, had to write with his audiences in mind and their desires in mind: compulsory heterosexuality. However, Clum argues and what I wish to argue is that it does not mean that his shows were not additionally intrinsically queer.

In this chapter, I will argue how Sondheim showcased and advanced notions of queerness on the inside, while showcasing heterosexuality on the outside. Doing so is a deliberate political move. On one hand, it is playing within the confines of the system of the time. While there are exceptions, Sondheim was confined by what was allowable. What this allows, however, is for a unique political message to resonate with those of the community. The message that one gets from Sweeney's rampage, or Robert's reluctance to get married can be vastly different for someone in the LGBTQ community than someone who is straight. In essence, this chapter aims to address: what does it mean to be Queer in America? 
For the purposes of this chapter, gay will be used to describe someone who identifies as a male who is sexually or emotionally attracted to other men. Queer will be used as an umbrella encompassing term to describe anyone who is not straight or cis-gendered and can include varying sexualities and genders.

\section{Company}

Perhaps the show that is often cited the most for this applicability of queer undertones is Company. Company was Sondheim's first post-Stonewall show and opened on Broadway in April 1970. The show, which focuses on Robert, his three girlfriends and 5 married couples who were his friends, was meant to ignore the typical escapism that Broadway had typically afforded people. In Broadway: The American Musical by Michael Kantor and Laurence Maslon, Sondheim recounts this by stating:

Company does deal with a lot of so-called brittle people-upper-middle-class people with upper-middle-class problems, but I think the audience in those days was an upper-middle-class audience... They couldn't say, "Oh, that's that world of people" 'cause they were that world of people...It's no joke, that cliché that musicals are escapist entertainment and [audiences] really want to escape. And here we're bringing [their problems] right back in their faces. What they came to a musical to avoid they suddenly find facing them on stage. (Maslon 333)

So how does a show that talks about upper-middle-class people and problems, which outwardly show heterosexual relationships have anything to do with queerness? The answer lies inside the main character. The debate over Company lies in whether Bobby is or is not gay-something that even Sondheim had fought against for years as well. I wish to argue, that despite the reasoning against the notion, that Robert is indeed gay. The sexuality surrounding Bobby's 
sexuality is important to identifying Sondheim as rejecting societal norms. By having Bobby be gay, Sondheim makes the problem Bobby has into being “...gay in a society where being gay means not having a fair chance at intimacy..." (The 1). If Bobby's sexuality were not important, Sondheim would just further reinforce the notion that a man can be "normal" (which should be read as "straight"), even if he sleeps around and has sex with other men. It would reinforce the stereotype that being gay was sinful or something of which you should be ashamed. In other words, if you were gay, you would not be able to have a normal life. By having Bobby be gay, Sondheim is rejecting this notion and is commenting on this very notion.

Director Scott Miller in 1995 attempted to request the production be able to cast two men for one of the couples. For Miller, he argued that to move forward, the musical must acknowledge the changes surrounding marriage and same-sex relationships that had occurred in the 25 years. He stated “...Company isn't just about marriage. It's about sustaining a long term commitment in our increasingly mechanized and depersonalized society" (Turner 69). This would support Harold Prince and his thoughts on the show. Harold Prince is quoted as stating: "it examined people who don't want to get married. More importantly, it examined the willingness to commit yourself to another human being, marriage or not. That certainly was the central issue in our society, then. Since that day, think of all the people who live together and aren't married, so it has changed, big time" (Maslon 332). However, despite this argument, Sondheim, and Music theatre International denied Miller allowing one of the couples to be gay. This is intriguing, because in the 1995 version of the show produced by Donmar Warehouse, the show included a scene that was cut from the script before opening in 1970. The below scene from Act 2, Scene 3 helps to illuminate why exploring Robert's sexuality is so important. If we simply view Robert as straight, who has sex with other men, we will see the damaging effects of 
Sondheim reinforcing the stereotype that being gay is abnormal and cannot lead to a happy life.

Instead, if we view it as Robert being Gay, we can see Sondheim showcasing this struggle for the LGBTQ to have a fair chance at intimacy and thus commenting on society. The scene goes:

PETER. Robert, did you ever have a homosexual experience?

ROBERT. I beg your pardon?

PETER. Oh, I don't mean as a kid. I mean, since you've been adult. Have you ever?

ROBERT. Well, yes, actually, yes, I have.

PETER. You're not gay, are you?

ROBERT. No, no. Are you?

PETER. No, no, for crissake. But I've done it more than once though.

ROBERT. Is that a fact?

PETER. Oh, I think sometimes you meet somebody and you just love the crap out of them. Y'know?

ROBERT: Oh, Absolutely, I'm sure that's true.

PETER. And sometimes you just want to manifest that love, that's all.

ROBERT. Yes, I understand. Absolutely.

PETER. I think that sometimes you can ever know someone for, oh, a long time and then suddenly, out of nowhere, you just want to have them-I mean, even an old friend. You just, all of a sudden, desire that intimacy. That closeness.

ROBERT. Probably. 
PETER. Oh, I'm convinced that two men really would, if it wasn't for society and all the conventions and all that crap, just go off and ball and be better off for it, closer, deeper, don't you think?

ROBERT. Well, I—I don't know.

PETER. I mean like us, for example. Do you think that you and I could ever have anything like that?

ROBERT. (Looks at him for a long and uncomfortable moment. Then a big smile): Oh, I get it. You're putting me on. Man, you really had me going there, you son of a gun.

(Laughing, Robert points at Peter and exits. Peter, alone, opens his mouth to call after him but doesn't. Peter exits. Blackout). (Sondheim, "Company" 103).

Jeff Turner in his essay "Commercial Necessities: Reviving Stephen Sondheim and George Furth's Company at the Turn of the Millennium” in the Journal Theatre Symposium states that this interaction can be read in two ways:

First, the scene underscores Bobby's ambivalence about relationships in general. As Billington noted, "Sondheim now even addresses the question of whether Robert is gay: the answer is just a little but never quite enough." A second reading suggests a level of authorial declaration. From this perspective Sondheim and Furth shut down the debate around the central character's sexuality. (Turner 70). I am reluctant to agree with the latter. This is because it suggests a level of authorial declaration and that argument would not make sense with the 11 o'clock number. This show we see Robert struggle with finding happiness - that intimacy that he desires — simply for his sexuality. Part of 
this is not just because it was abnormal during this time but is also due to Robert's coming to terms with his own sexuality. The 11 o'clock number, "Being Alive", encodes hidden meaning of Robert's nuanced realization of his sexuality. It is when Robert finally realizes who he is, what he wants, and is okay with it. Despite what society tells him, he can be happy, and he can find love. It is the ending of this song that is most poignant to my argument:

AMY. Blow out your candles, Robert, and make a wish. Want something, Robert!

Want Something!

ROBERT. Somebody hold me too close,

Somebody hurt me too deep,

Somebody sit in my chair

And ruin my sleep and make me aware

Of being alive, being alive.

Somebody need me too much,

Somebody know me too well,

Somebody pull me up short

And put me through hell and give me support

For being alive.

Make me alive,

Make me alive.

Make me confused,

Mock me with praise, 
Let me be used,

Vary my days.

But alone is alone, not alive.

Somebody crowd me with love,

Somebody force me to care,

Somebody let me come through,

I'll always be there

As frightened as you,

To help us survive

Being alive, being alive, being alive. (Sondheim, "Company” 116).

In these last couple stanzas, Robert transitions his thinking from rejecting to wanting. He wants someone to hold him close, to give him support, and most importantly, to help him come alive. For Robert, he is looking for somebody to let him become his true authentic self——which I would argue is an indication of his non-heterosexuality. If he was heterosexual, then that would have happened already — with one of his many girlfriends that he has had, he would already have come alive. The fact that it did not happen is telling. Additionally, in this last stanza he states that he will always be with this person, as frightened as he himself, to help them both survive and be alive. I argue that this is an analogy for "coming out". Company came out in 1970 and was right on the heels of the Stonewall Riots. Being gay or bisexual was not mainstream at this point and coming out was a serious commitment. Jobs, family, economic security, and more were all real dangers of what one could lose by coming out. So, it was a scary process in which one would need strength. The LGBTQ movement encouraged people to come out to “...end internalized 
self-hatred and achieve a better life" (Saguy 1), which is exactly what Robert is singing about in "Being Alive". He is not able to be his authentic self and is looking for that person to love and support him through the process, just as others in the LGBTQ movement look to others for support. His fear for intimacy or a relationship is not that he is straight. I would argue that it is instead a product of the time in which the character was living. With the close mindedness, and the discrimination that many in the community faced during this time, it makes sense why Robert would be hesitant of "Being Alive" to his true authentic self for someone he truly matches with.

My argument aligns with other scholars, including Clum. In his book, Clum asserts that it was the proposition from his male friend, as well as from a drag queen, that brought Robert to this realization that culminated in "Being Alive". Clum notes:

After "Being Alive," Bobby disappears to start a new life apart from the world of his married friends. Gay men read Bobby's disappearance as a move from the world of compulsory heterosexuality, the usual world of the musical, to an uncharted, unseen world of homosexuality. Otherwise, why cut all ties? In 1970, coming out often meant cutting ties with one's straight friends -or we thought it did. And the society of those friends - being the third at dinner, the baby-sitter to their kids - was often a way of staving off loneliness and the feared plunge into what was still a mysterious, frightening, gay possibility. (Clum 222).

Clum further asks would a straight man be 35, using his formal first name (no nick name), while lethargic in bed with women, but the "safe best buddy of half a dozen wives"? Clum asserts the answer is no. Clum further asserts that Sondheim's initial lyrics for the song "You Could Drive a Person Crazy", in which his girlfriends are singing is a hidden message encoded in the show when they sing: 
I could understand a person

If a person was a fag. (Sondheim, "Finishing The Hat" 177)

For Clum, and many gay contemporaries of his, the biggest telling of the queer reading of Company was that it spoke Truth. Truth of their lives, Truth of their experiences, and Truth of their process of coming out. Despite their insistence that Sondheim's Company had gay elements, both with Robert's character and multiple other hints hidden within, they understand why Sondheim would have caution. For placing any sign of “...gayness on the stage other than a comic travesty of a sissy or a sensitive, suicidal young man was critical censure" (Clum 223). Robert's response to Peter questioning him allows for us to see Robert's struggle to fully come out or accept that he is gay. In the scene Robert takes long silences which I view as contemplation and nervous laughs which helps to showcase how Robert is feeling a sense of embarrassment, stress, or uneasiness. These support the fact that Robert is coming to terms with his sexuality. If Robert were straight, he would be able to answer no, without hesitation and authority. Robert's hesitation and reluctance to give a straight answer helps to counter this argument.

In recent years, Sondheim has opened the possibility for different interpretations of Robert. Despite Sondheim still insisting that gay reading of Robert was not their intent in a 2000 interview, he did offer the notion that it might have been the result of the subconscious through the writing process. However, in 2013, Sondheim appeared open to making the character gay in a refreshed look at the script. In an article titled "Sondheim Working on Revised 'Company" in The New York Times by Patrick Healy, Sondheim stated that a proposal making Bobby Gay “...intrigued him. "It's still a musical about commitment, but marriage is seen as something very different in 2013 than it was in 1970," he said. "We don't deal with gay marriage as such, but 
this version lets us explore the issues of commitment in a fresh way."' (Healy C3). While ultimately, Sondheim felt that it just did not work after a readthrough of the new show, the answer, for many is painfully clear. In a 2013 article in The Atlantic titled "Stephen Sondheim Reworking Seminal ‘Company’ to Make Lead Gay”, Esther Zuckerman mentions James Jordan, a writer for Capital New York, about why the show, even 40+ years later, still does not answer the central question for Robert being unable to settle, "because Sondheim and Furth have taken the number away: the nature of Robert's sexuality" (Zuckerman 1). Jordan goes on to explain how Sondheim and Furth's estate always denies people who request to make Robert gay. Jordan goes further and states:

"Robert's 'problem' is not that he's gay," Jorden concludes, after exploring changes Sondheim and Furth had made to questions of Bobby's sexuality. "Rather, it's that he's gay in a society where being gay means not having a fair chance at intimacy, if for no other reason that he himself doesn't understand his sexuality. And it doesn't matter if the people who created Robert protest: after all, when they wrote Company, they didn't understand their own sexuality either." (Zuckerman 1).

A revised concept of Company, in which gender swaps occur of several characters, did win the approval of Sondheim. While this production has been critically well-received, it still does not answer the centralized question that has been on everyone's mind since the 1970's. In fact, gender swapping, while powerful and helps answer questions among gender and other intersectional identities, really does little to provide significant answers to a gay interpretation of Sondheim's work. 


\section{Sweeney Todd: The Demon Barber of Fleet Street}

Sweeney Todd opened in 1979, approximately 10 years after the Stonewall Riots. The show, which focuses on a murderous serial killer and features no gay characters, is still considered by many to be a gay show. When first hearing songs for the show, Secrest recounts how Judy Prince exclaimed to Sondheim "It's the story of your life" (Secrest 295). While Secrest seems hesitant on making a direct connection to Sondheim's life of a gay man and its direct connection to Sweeny Todd, I do wish to push back some and think that it is worth analyzing Sweeney Todd from a queer lens. Whether intentionally or not, there are several queer elements within the show that deserve recognition and that might help answer how this show can be thought of as a gay show.

Internalized homophobia is a result of being taught that heterosexuality is the norm in society and what is the "correct" way to be. One way that internalized homophobia can be manifested in someone who might be gay is by projecting anti-gay prejudice on other people or onto themselves. We can visualize internalized homophobia in the actions of Judge Turpin, especially within his rendition of "Johanna". For the record, Johanna is essentially Turpin's daughter (was raised by him), whom he falls in love with and sexualizes over, and eventually wants to marry. "Johanna", when sung by Judge Turpin, is him stuck between his sexual desire and the punishment and guilt that he has based on society's standard. He knows that society views his feelings as bad, and he as judge, must administer punishments for those who have those feelings, which ultimately means he must administer punishments to himself. One stanza that stands out particularly powerful to me in his rendition to illustrate this point. Turpin sings: Johanna, Johanna

I cannot keep you longer 
The world is at your window,

You want to fly away.

You stir me, Johanna

So suddenly a woman,

I cannot watch you one more day-

(Again whips himself into a frenzy)

God!

Deliver me!

God!

Deliver me!

God!

Deliver-

(Climaxes) (Sondheim, "Sweeney Todd" 70).

From a queer lens, the judge's actions - his struggle between what he desires and what is socially acceptable, can be a metaphor for internalized homophobia - the struggle between being gay and living how one has been raised and taught within their culture. Just as Judge Turpin-many might engage in activities that they enjoy or like but are immediately blasted with guilt or anger as if something is wrong.

We can also read this scene going a step further and look at the physical actions of the judge. Throughout the scene, we see him administering punishment to his body in the form of whippings. These whippings increase in frequency and the stage directions literally describe this as "(Again whips himself into a frenzy)". The climax of the song literally brings him to the brink of no control and produces a climax from the judge. This element of the physical actions, 
through a queer lens, could be seen in two different lights. One, we can see it as a further argument for the Judge's internalized homophobia during "Johanna". His self-flagellation is the physical punishment that he administers to himself for being gay. It is the punishment that he must receive for being something out of the ordinary. On another hand, we can also see this as a metaphor for BDSM (an encompassing term for bondage and discipline, domination and submission, and sadism and masochism). BDSM, when done within the LGBTQ community, helps to challenge heteronormativity and the perceived differences in masculinity between people who are gay and people who are straight. It allows for the script to be flipped and reverses the power dynamic that is often set up in heteronormative society. Leo Bersani's discusses this concept in his article "Foucault, Freud, Fantasy, and Power" from GLQ: A Journal of Lesbian \& Gay Studies, he writes:

$\mathrm{S} / \mathrm{M}, \ldots$ is an "unadulterated reclamation of masculinity" on the part of those who have been excluded from that worthy ideal: gay men. ... "in S/M and the powerful initiation into archetypal masculinity that it represents, gay men have found a way to reclaim their primal connection to the rawness and power of the Masculine, to give a patriarchal, heterosexist society as tinging slap in the face by calling upon the masculine power of men's connection to men to break the boxes of immaturity and effeminacy into which we as gay men have been put"...

Everyone gets a chance to put his or her boot in someone else's face. (Bersani 18) One way we can view the judge is not just as exerting internal homophobia onto himself, but also include playing with the power that society and he have through his role as a judge vs. the power he has with his sexual self. This struggle with power between the two, his lust, and the physical fact that he climaxes in the moments following him whipping himself into a frenzy makes this 
metaphor even stronger. Considering this connection to BDSM, and Bersani's article, also brings me to another element in the show that is worth analyzing, and that is "Epiphany", at the end of Act I. In the song between Todd and Mrs. Lovett, Sweeney sings:

TODD. Because in all of the whole human race, Mrs. Lovett, There are two kinds of men and only two.

There's the one stay put

In his proper place

And the one with his foot

In the other one's face-

Look at me, Mrs. Lovett,

Look at you! (Sondheim, "Sweeney Todd" 101).

Again, we see the lyrics and its metaphor to the power dynamic between those in power and those not in power. Both in the song, as well as in Bersani's article is the image of the boot. Both the article and the song discuss the boot in a way that the lower class wants to be able to be the one that puts the boot on someone else-the regular heterosexual society. For BDSM, it is to reclaim a sense of masculinity for the people who have been made effeminate by heteronormative society, and in Sweeney's case, it is to reclaim a sense of power against a society. In both cases, one can see it as a sense of revenge to the world.

This revenge that Sweeney possesses was illustrated earlier in "Epiphany". Earlier in the song, Sweeney sings:

There's a hole in the world

Like a great black pit

And it's filled with people 
Who are filled with shit

And the vermin of the world

Inhabit it-

But not for long!

They all deserve to die! (Sondheim, "Sweeney Todd" 101).

Sondheim Scholar, Robert L. McLaughlin points to this song in a 1991 article titled "“'No One is Alone": Society and Love in the Musicals of Stephen Sondheim" in The Journal of American Drama and Theatre. McLaughlin notes “...Sweeny decides to revenge himself on the entire system that has victimized him, one person at a time. In his thinking, the powerless are as guilty as the powerful because they are all participants in the system" (McLaughlin 33). Taking McLaughlin's analysis, a step further, this revenge that Sweeny has can serve as a metaphor for the revenge that many gay folks might have against the heterosexual world. Like Sweeney, who has been victimized by society, so too have people identifying as gay been victimized by society. While Sweeney at first only wanted to get his revenge on the judge (who is "the power", "the law", "the creator of standards and norms"), Sweeney ultimately turns to wanting revenge on society. McLaughlin's note about the powerless being complicit can help explain Sweeneys thinking. So too, can we begin to see parallels between Sweeney's thinking and the thinking of modern political and social movements for rights of minoritized communities, including the modern LGBTQ+ movement. In both instances (the movements and the musical), those who have been victimized are calling out how, while people may not have power, by remaining complacent and participating in society without demanding accountability or change, makes them complicit with the actions being done. In essence, they are just as guilty as the one creating 
the rules and enforcing the standards. Sweeney's anger therefore is a metaphor for the anger in the gay community. Clum reminds us that "such anger resonated with key moments in gay history of the past thirty years as much as the cleverness, camp, and irony. Perhaps that's what's gayest about Sondheim: the fusion of anger and irony once considered a crucial element of the gay stereotype" (Clum 216). Indeed only 10 years earlier, did this anger boil over at Stonewall, when the LGBTQ+ community fought back against the law, just how Sweeney did 10 years later.

\section{Road Show}

Despite being one of Sondheim's newer shows, and featuring an explicitly written gay character, Road Show is filled with dozens of nuances that complicate the question of what Sondheim's political stance on the issue is. Despite its numerous elements that might question whether Sondheim is taking a positive political stance on queer issues, I argue that Sondheim ultimately takes a positive stance for LGBTQ+ rights with this show.

Before we begin, we must know a bit about this show. By the time it opened in 2008 at The Public Theater in New York City, it had already gone through several revisions, in which plot points, songs, and the name of the show had been changed several times. Originally known as Wise Guys, and later as Bounce, the show had been an idea that Sondheim had had in his head for nearly 50 years. For my thesis, I will be talking about the 2008 edition of the show that opened Off-Broadway in New York City. The show, which was loosely based on Addison and Wilson Mizner, follows the brothers from the gold rush to the booming Florida housing market that was seen before the great depression.

One of the struggles with interpreting this play through a queer lens is how the show is written. While there are moments in which Sondheim pushes back against societal norms that 
have come to define people who are gay, there are also moments in the show, equal in number, that can be interpreted as Sondheim reinforcing these dangerous notions. Those moments in which Sondheim pushes back against societal norms traditionally center around scenes between Addison and Hollis, while moments that reinforce social norms are traditionally centered around scenes between Addison and Wilson. While these moments are ultimately hindering the show from being completely positive, I do feel that the overall goal was to take a positive political stance through the show. These elements combined, complicate viewing this musical through a queer lens and can lead to confusion around the positionality Sondheim is trying to take.

First, I want to analyze scenes that are the most troubling and those center around Addison and Wilson. The first scene is from early in the show when the brothers are in Alaska and are featured in the song "Brotherly Love". Wilson, whose sleeping bag is wet and torn in the middle is offered a spot in Addison's sleeping bag which is much warmer. They spend time reminiscing about times past and fond memories.

ADDISON. You always looked out for me, no matter what...

WILSON. Just brotherly love, brother, brotherly love(Sniffs)

Jesus, I smell.

ADDISON. I'm not sorry I came, Willie.

Just as long as you're here...

(The wind rises as the music fades. Addison looks suddenly uneasy. He pivots away nervously so that he and Wilson are back to back.)

WILSON. Turn around, will you?

ADDISON. I'm fine like this. (Sondheim, "Road Show" 27). 
This scene is complex. One of the biggest complexities is Addison's love for Wilson. In this scene, Addison shows that he has intense love for Wilson. In an interview with DC Theatre Scene, Sondheim states: “Addison is in love with Wilson. He knows he's dangerous, but he can't break away from him" (Horowitz 1). Many directors have played this scene as if Addison has suddenly got aroused, became embarrassed and turns around. This view of the brother's relationship makes sense as Sondheim continues to comment about Wilson. Sondheim states: "He gets what's going on. He lives his life attracting people. That's what a conman has to do that's the one skill he has to have" (Horowitz 1). From a queer studies perspective, this scene can be very problematic. First, one can interpret this as a love that is more intense than loving a family member. From the perspective that Addison has gotten aroused, it could be argued that this scene is playing into certain stereotypes that those who are gay are obsessed with or engage with incestual relationships. Furthermore, Sondheim's comments about Wilson reenforces stereotypes that those who are gay are just attracted to how people look and not concerned about any other feature of someone. These can be dangerous stereotypes to reinforce due to the inaccuracy of them and the dangers that inaccurate stereotypes can have in misleading individuals.

Later in the show, Wilson comes to visit Addison and their mother at Addison's New York City apartment. Shortly after their mother's death, Addison and Wilson get into a very verbal and physical fight, with Addison threatening Wilson with a knife. Taken from a queer context, this scene is problematic as it reinforces the negative stereotype that people who identify as gay are hysterical, angry and their only inclination is to fight. In his book, Clum reminds us that anger was "Once considered a crucial element of the gay stereotype" (Clum 216). From an equity standpoint, it points to Wilson as being the victim and Addison as the aggresse, despite 
Wilson being the one that is never around and being an instigator to the argument. From this viewpoint, stereotypes of the gay guy being the "dangerous" or the "crazy" one is upheld, while the sympathy goes back to the straight character-the one that represents typical society.

In the final scenes of the play, we see this unique relationship between Wilson and Addison play out. Throughout the show, we see Addison falling into a vicious cycle with Wilson. This cycle includes Wilson's appearance, getting Addison to go along with him, and Addison ultimately being on the losing end. The results of this have resulted in Addison losing just about everything — his parents, his dream, his significant other — a good representation of what people who come out often lose. While this is an honest portrayal of what often happens, Sondheim mixes this up with Wilson being the "attractive" guy and Addison falling and losing his agency. In the scene, Addison is trying to get Wilson to leave him after it is realized that Wilson's ideas and work were all a scam. Despite Addison telling Wilson to leave, Wilson will not leave and instead keeps on pushing back and making excuses.

WILSON. Admit you don't want me to go.

WILSON. Come on, Addie, you love me!

Come on, say it out loud!

Come on, Addie,

You love me, you love me,

You've always been-—!

ADDISON. All right, yes!

I love you, I always have loved you! 
Does that make us even?

Does that make you happy?

And I want you to go.

(Beat)

And, no,

I don’t want you to go. (Sondheim, "Road Show" 96).

This scene showcases Addison's loss of any agency that he still had left for himself, which plays into harmful stereotypes that those who are gay can be lead astray, that straight individuals can get gay people to do what they want, and that those who are gay will do anything for people who look a certain way. We can also see Wilson force Addison to admit that he loves him, like how individuals may force someone to come out with their sexuality, even if they are not ready. Doing this can have negative repercussions and having this reenforced through the show can be a sign of complicity with this idea. Just like the other scenes above, we can see that this scene helps to reinforce societal stereotypes and misconceptions and can be opposite of what an equitable or diverse play should be trying to accomplish. Currently, the scenes seem forced, as if Addison is being “outed” by Wilson. If Sondheim had made Wilson less forceful and demanding, and Addison with more agency, and willing to admit that he wanted Wilson, then that could greatly change my perspective of the brothers. For now, it seems forced which makes it seem relatively opposite to current society's emphasis on consent and respect.

While I have talked about the nuances that seem to suggest that the show is reinforcing societal stereotypes, there are moments in which Sondheim pushes back against these norms as well, and those I feel are powerful political moments for the show. These moments, as I 
mentioned earlier, can be seen mainly through the relationship between Addison and Hollis. While at first it may seem as if Sondheim might be reinforcing stereotypes that men cannot be successful in more feminine careers such as the arts and design, the show in facts ends up doing the exact opposite and shows that those careers are viable options. While Hollis was kicked out of his home for being more interest in the arts than commerce or industry, he meets Addison on the train and Addison decides to join him, realizing that Hollis' family connections might ultimately lead to his architectural designs being accepted and finding success. It in fact does lead to Addison being a successful architect. This helps show how design and architecture can be a fulfilling career, despite it not being STEM focused. Addison will support Hollis in his dreams of creating an artist colony, in getting rich financial backers from people who have Addison design their homes. While this scene can be viewed as problematic (especially with the fact that it is only the women who verbally support the idea of the artist colony), I view it as a reaffirmation that it can be done. This is because Sondheim is reaffirming that the arts or similar professions are viable and reject societal norms that might indicate that those who pursue these careers cannot lead to success. Had Sondheim wanted to reinforce this notion, no one would have supported the dream for the artist colony. Why would individuals invest in something that is not "worth it". Instead, by showing the success, as well as the temporary happiness between Addison and Hollis, helps for Sondheim to argue that these careers can lead to happy, fulfilling lives.

In the early 2000's, it became necessary for Sondheim to redevelop the relationship between Addison and Hollis. While in real life Hollis is based on Paris Singer who was not gay, but just a work colleague. Sondheim decided to deepen the relationship into an intimate gay relationship. This gay relationship was important for representation and reflecting the changing 
societal and cultural norms of the American population in the $21^{\text {st }}$ century. The relationship between Addison and Hollis also helps show that those who are gay can find love and significant others. Just like the "others" in society, stereotypes exist that those who are gay just sleep around and make no meaningful connection or societal contributions. Sondheim rebukes this by showing Addison and Hollis going into a relationship and having them sing a song that each one is perfect for one another and make their lives complete. While each ultimately gets something from the other, they support one another and give each other that person in their life that they have been searching for. While the relationship does not last forever on a happy note- - Hollis will ultimately leave Addison after Wilson's antics, the fact that they were able to find one is significant. One could also argue, if it were not for Wilson, there is a chance that they would stay together, helping rebuke the stereotypes even further. Again, like Company the importance of Hollis is for Sondheim to argue that if one identifies as Gay, then they can find happiness. Despite society and straight narratives trying to ensure that those of differing sexualities or genders cannot find happiness or success, Hollis and Addison's relationship helps to confront this. If Addison had been placed in a straight relationship, Sondheim would just be further replicating society standards that only "straight" can be normal and nothing else.

When it comes to this show, as a scholar, I cannot ignore the complexities and nuances that this show offers. While there are moments between Addison and Hollis that reject societal norms and stereotypes, there are also moments in which harmful stereotypes can be seen and it is hard to look past these moments. For being a show with the first openly gay character written in Sondheim's cannon, I wish he would have done more work to address the notions that he upheld through certain scenes. While I can respect that he was trying to comment on the brotherly relationship, in the end I would argue that he did more harm than good when it came to the 
repercussions on gay stereotypes. That being said, I do feel that the relationship between Addison and Hollis comments more loudly in the show and makes up the bulk of the plot and is directly more political than the other elements. I believe this because this aspect of the show is explicit in what it is trying to do. The relationship between Addison and Wilson is more subliminal—it is more reading between the lines. The relationship between Addison and Hollis is direct—and Sondheim and his collaborator made the explicit decision to directly showcase queer issues in a positive light (despite the relationship not working out in the end). This positive outlook (the notion that other professions are worthy, having a relationship with someone of the same gender is okay and can lead to happiness), speaks loudly to the audience and I feel helps to ultimately solidify the creators intentions with the show.

\section{Conclusion}

Like the previous chapter, each of these shows, while vastly different in plot, have a thread that runs through them all. That is, they passionately speak to queer issues that are present in the lives of the LGBTQ+ community. Whether these connections were directly commented on, as in Roadshow, or indirectly, as in Company, and Sweeney Todd, they spoke to a multitude of issues including love, relationships with society, friends and family, and acceptance. To accomplish this, in each of these three shows, Sondheim has used characters that help Sondheim push back against the stereotypes that come with being labeled the "other". One of the biggest stereotypes that Sondheim pushes back against is the notion that those who are not "straight" cannot find happiness. They cannot find love; they cannot find intimacy—-they are unable to find and obtain the things that they want. In each show, Sondheim puts characters in pursuit of finding their true happiness (whether it's intimacy, love, success) and the battles between the struggles that straight heteronormative society has put up as roadblocks. For Sondheim, he is 
commenting on these roadblocks that exist in society, and I argue, is helping to expose how detrimental they are to society.

Each of the shows are not just a pursuit for happiness, but also a pursuit for acceptance. In each show, we see metaphors for internalized homophobia that characters struggle with. This can be seen especially in Robert, The Judge, and Addison. Each must fight against their own internalized homophobia, and each goes on a journey to find their true authentic selves. The results for each vary. For Robert, he seems to have a more positive ending of self-acceptance, while The Judge could be seen as a less-than-ideal self-acceptance, and Addison goes back and forth with his internalized homophobia coming and going throughout his life. The fact that every character's journey is not the same or happy is excellent, because it represents reality. By Sondheim representing the battle against internalized homophobia in this way, he is representing real life and makes his work much more authentic to the lives of LGBTQ audiences. In this respect, Sondheim is making a political stance on this issue, and is indeed creating political theatre. 


\section{CHAPTER IV: SUMMARY, CONCLUSION, AND RECOMMENDATIONS}

I started this thesis with a question to answer. When it comes to theatre post COVID-19, what will the "new normal" be? While I cannot be certain what the entire future might bring, I argue that Sondheim should continue to be included in our search for a new normal.

I argue that Sondheim is a political theatre artist. His shows are political in nature. While a theatrical work is the result of many people-filled with collaborators from the creation through the production process, I don't think this diminishes Sondheim's political aspects. For most of my analysis, I have focused extensively on elements from the lyrics that Sondheim wrote (some exceptions do apply). In this case, Sondheim used his position as a lyricist, as a tool to get across to the audience political messages in both subtle and explicit means. The theme of these political messages has focused heavily on what it means to be a woman or queer in America?

In chapter 2, we explored Sondheim's political messages for when it comes to discussing the historical role, and the role that could be for women. Whether in the workplace, in the bedroom, or in the home, Sondheim's shows critique societal and cultural stereotypes and norms that existed for women and instead advocated for women's advancements and liberties.

In Gypsy, through the relationship between Herbie and Rose, we explored how the show presented flipped gender roles and how that compared to gender roles that were prevalent then and now. We analyzed the male-centric theatre business through Rose's interaction with theatre owners, particularly Mr. Grantziger, with her desire to have her daughters become stars. Through Louise's eventual success with stripping, we also touched on female empowerment and control over their bodies - giving agency to one to love themselves and not allow others to dictate what they must do with their bodies. Perhaps most importantly, we experience Rose's journey—one that has always rejected societal norms of the woman staying-at-home and see her complex 
journey in which she finally gains agency to allow herself to show emotion and not seen as the "hysterical woman".

A Little Night Music was instrumental in commenting on women and sexuality. Through the show, we see a liberal view of women and sexual activity-something that was often counter to what traditional values seemed to uphold. While some of the sexual activity, such as Petra's, was done simply for fun, others such as Madame Armfeldt did it to help gain success. It showed that women were just not there for men's sexual use and enjoyment, but instead, they too, deserved the right to engage in it for their own enjoyment. This aligns with the sexual revolution that was prevalent and running rampant when the show was written. It also commented on traditional family and gender roles that were commonplace-featuring women who were not married being successful, as well as engaging in professional careers that were not seen, at the time, viable for women.

In Into the Woods, we see the characters fight against the binary heteronormative system that has come to dominate our world. We see women, such as the Bakers Wife, reassert herself as a power player to her husband, and allow to break away from the binary system and have a “and" instead of just always having an "or". We see Cinderella have agency that most interpretations of her story have not given her. We see her take her fate and purposefully leave a shoe behind because she wants the prince to find her. More so, Cinderella is given the agency to leave her prince charming when he has not been faithful and does not give into what the man in the relationship wants to do. Finally, with Little Red Riding Hood, we see her using her own thoughts and ideas to guide her — allowing her to make decisions for herself — not allowing others. 
In chapter 3, we transitioned to exploring Sondheim's political messages with regards to queer issues. In this chapter, we explored how Sondheim showcased and advanced notions of queerness on the inside, while showcasing heterosexuality on the outside and how doing so was a deliberate political move. This allowed for a unique political message to resonate with those of the queer community and ultimately helped to address what it means to be queer in America.

In Company, we discussed the issue that surrounded the main character, Robert, and his sexuality. Despite Sondheim's best attempts to claim that sexuality has nothing to do with the character, many aspects of the show, seen through a queer lens, counter this argument. Indeed, many of the actions that Robert takes can be viewed through a queer lens as different actions that one might take when coming to terms with their own sexuality. An example of this is, "Being Alive", which can read as a metaphor for the coming out process. Another example that was discussed is his interactions with Peter, and how while some might view it as a joke, I argue that it is Robert struggling to understand or come to terms with his own sexuality. For many in the LGBTQ+ community, they can relate to Robert's experience and find comfort in Robert's ultimate acceptance of himself.

In Sweeney Todd, we analyzed how the Judge's actions during "Johana" could act as a metaphor for internalized homophobia. The judge struggles between his own wants and sexual feelings, with what the world dictates is right and how he administers as judge. We also explored the connection between the judge whipping himself into a frenzy and climax to a larger discussion of BDSM and power relationships. This led to an analysis of Sweeney Todd, and the revenge against society that could be read as a revenge against the straight, heteronormative society. 
Finally, in Road Show, we explored whether Sondheim's show with the first openly gay character helps gay representation on the stage. While we discussed how there are moments that Sondheim seems to reject societal norms, such as showing that a career as a designer or architect can be fulfilling, there were many other moments in which norms were upheld, including moments in which Addison seemed to reinforce the hysterical, angry gay stereotype, as well as the one that lusts for anyone attractive. In addition, Addison loses nearly everything he has and is seen as a metaphor for if someone is gay, they cannot find success or happiness.

These shows, I argue, help to showcase that Sondheim and his shows are indeed political. Especially poignant is that they have been political from the day that they were first created and continue to resonate today. While the ultimate meanings might have changed (being part of the LGBTQ+ community is much more accepted in certain segments of society than it was), they still take strong political stances on issues that continue to divide society to this day. Indeed, the past 5 years have showed our political landscape with women's and LGBTQ+ rights being on the forefront of who gets to enjoy the liberties and rights this country can offer.

Before I started this project, I enjoyed Sondheim because of its entertainment value. My first experience with Sondheim was with Into the Woods and it immediately hooked me with its creative take on classic tales that make up much of our childhood. As I grew up and moved into a position where I wanted to pursue theatre in a more serious way, I began to see how shows were not just for entertainment — that they too, discuss important ideas and messages. Even with shows that I personally may not have found as entertaining, such as Brigadoon, I began to see that each show has a message, and that message has power. The arts, like all entertainment, have a vast audience that allows it to convey meanings. As I have transitioned into a professional and scholar, I have begun to see the intricate layers of these meanings, especially with Sondheim and 
his shows. I believe that the best type of theatre is one that leaves with you when you leave. The ideas that you carry should provide provocation and leave you asking questions. I have discovered that part of my love for Sondheim was not just because it was entertaining, but that it was leaving the theatre with me — subconsciously and consciously having different thoughts, ideas, and feelings wrangling around in my head. This is the power of theatre. Through my use of analysis, I can finally dive deep into the connective tissues of the shows, and by using certain lenses, such as feminist and queer theory, I can begin to make meaning and find hidden messages besides what is being shown on the stage. I can begin to find the treasure that is at the end of the treasure map and continue to explore what Sondheim is trying to say. Most importantly, it taught me the courage, the struggle, and the ultimate accomplishment that Sondheim, his collaborators, and hundreds of theatre artists had in the past, and currently, as they advocate for a more inclusive society and world. A world where everyone has value and is welcome, and where everyone can be who they are.

Future studies are ripe with possibilities. Future scholars have multiple angles that they might consider using to continue this type of study. First and foremost, we only discussed 6 of his shows. There are numerous others that are just as complex and deserving to be analyzed in a scholarly way. Indeed, a scholarly study of these other shows might bring about new ideas, thoughts, or revolutions that could help support my argument or create new arguments. Additionally, we only analyzed these shows through a gender and queer lens. There are many other lenses through which one might analyze these shows and lead to results that reinforce or contradict my findings. For example, my analysis focused solely on viewing performers or ideas through a cis-gender lens. Future studies might include a study with a transgender lens and lead to other conclusions. Additionally, I did not bring up race, or other intersecting identities, which 
could also lead to discovery of additional conclusions. As we move toward a more equitable and inclusive theatre, studies that consider the intersectionality of identities will be critically important.

So, what should the "new normal" of theatre be? While this question will certainly lead to hundreds of different answers, I think that there is one thing that would top my list and those of activists that have challenged the theatre community in recent years: a theatre community that is inclusive. A place where all voices, all backgrounds, all experiences are valued and portrayed, and we can begin to be reflective of America. After all, as America's artform, we should reflect what America is. To do this, we need to critically analyze and critique our past and decide what work's we should continue to showcase that help us reach this goal. To answer this, I argue that Stephen Sondheim should be included in the theatrical cannon as we move into this new normal. Through his political work that has historically and contemporarily rejected societal and cultural norms for women and folks of differing sexualities, Sondheim is an important voice to include as we work toward building an inclusive theatre community. Stephen Sondheim is a powerful ally and voice for so many who have often been silenced.

Stephen Sondheim truly gives us more to see. 


\section{WORKS CITED}

“The Missing Number in Sondheim's 'Company'.” Politico PRO, 2011, www.politico.com/states/new-york/city-hall/story/2011/04/the-missing-number-in-sondheimscompany-000000.

Bersani, Leo. "Foucault, Freud, Fantasy, and Power." GLQ: A Journal of Lesbian and Gay Studies, vol. 2, 1995, pp. 11-33., doi:10.1215/10642684-2-1_AND_2-11.

Clum, John M. Something for the Boys: Musical Theater and Gay Culture. St. Martins Press, 1999.

Evans, Laura. “Little Red Riding Hood Bites Back: A Feminist Reinterpretation.” Visual Arts Research, vol. 37, no. 73, ser. 2, 2011, pp. 128-132. 2, doi:10.5406/visuartsrese.37.2.0128.

Foucault, Michel. The History of Sexuality. Translated by Robert Hurley, vol. 1, Vintage Books, 1990.

Healy, Patrick. "Sondheim Working On Revised 'Company'.” The New York Times, 17 Oct. 2013, p. C3.

History, Art \& Archives, U.S. House of Representatives, Office of the Historian, Women in Congress, 1917-2006. Washington, D.C.: U.S. Government Printing Office, 2007. "Postwar Gender Roles and Women in American Politics," https://history.house.gov/Exhibitions-andPublications/WIC/Historical-Essays/Changing-Guard/Identity/ (March 09, 2021)

hooks, bell. "Feminism Is for Everybody." Pluto Press, 21 Sept. 2017, www.plutobooks.com/blog/feminism-is-for-everybody-bell-hooks/.

Horowitz, Mark. DC Theatre Scene, 2016, dctheatrescene.com/2016/02/09/stephen-sondheim-talksabout-road-show/.

Jones, Kenneth. "Stephen Sondheim Talks to Playbill.com.” Playbill, 7 Dec. 2010, www.playbill.com/article/stephen-sondheim-talks-to-playbillcom-com-174172. 
Laurents, Arthur, et al. “Gypsy: A Musical.” American Musicals: 1950-1969. The Complete Books \& Lyrics of Eight Broadway Classics, The Library of America, 2014, pp. 255-338.

Lorber, Judith. The Variety of Feminisms and Their Contributions to Gender Equality. BibliotheksUnd Informationssystem Der Universität Oldenburg, 1997.

Lovensheimer, Jim. "Stephen Sondheim and the Musical of the Outsider." The Cambridge Companion to the Musical, edited by William A Everett and Paul R Laird, 3rd ed., Cambridge University Press, 2017, pp. 247-263.

Maslon, Laurence, and Michael Kantor. Broadway the American Musical. 2nd ed., Applause Theatre \& Cinema Books, 2010.

McClouskey, Maddie. "In Praise of Women: Are Sondheim's Musicals Feminist.” The Sondheim Review, vol. 20, no. 4, 2014, pp. 15-17-5.

McLaughlin, Robert L. “'No One Is Alone': Society and Love in the Musicals of Stephen Sondheim." Journal of American Drama and Theatre, vol. 3, no. 2, 1991, pp. $27-41$.

Morgenroth, Thekla, and Michelle K. Ryan. "Gender Trouble in Social Psychology: How Can Butler's Work Inform Experimental Social Psychologists' Conceptualization of Gender?" Frontiers in Psychology, vol. 9, 2018, doi:10.3389/fpsyg.2018.01320.

New South Wales Department of Education. "Brecht - Political Theatre." Education, NSW Department of Education, 2020, education.nsw.gov.au/teaching-and-learning/curriculum/keylearning-areas/creative-arts/stages-4-and-5/drama/brecht-political-theatre.

Oakman, Richard. 'Momma's Gotta' Let Go: A Character-Driven Analysis of the Mother Archetype in Musical Theatre." University of York, 2017. 
Patches, Matt. "Anna Kendrick on Into the Woods, Impressing Sondheim, and Her Feminist Cinderella." New York Magazine, 2014, www.vulture.com/2014/12/anna-kendrick-on-into-thewoods.html?wpsrc=nymag.

Paulson, Michael. "Broadway, Symbol of New York Resilience, Shuts Down Amid Virus Threat.” The New York Times, The New York Times, 2020, www.nytimes.com/2020/03/12/theater/coronavirus-broadway-shutdown.html.

PBS. "The Pill and the Sexual Revolution." American Experience: Women in American History, Public Broadcasting Service, www.pbs.org/wgbh/americanexperience/features/pill-and-sexualrevolution/.

Rich, Frank. "Conversations with Sondheim.” The Sondheim Review, vol. 17, no. 1, 2010, pp. 2232.

Rubin, Gayle S. “Thinking Sex: Notes for a Radical Theory of the Politics of Sexuality.” Culture, Society and Sexuality: a Reader, edited by Richard Parker and Peter Aggleton, 2nd ed., Routledge, 2007, pp. 143-179.

Saguy, Abigail C. "The History of 'Coming out,' from Secret Gay Code to Popular Political Protest." The Conversation, 2 Mar. 2020, theconversation.com/the-history-of-coming-out-fromsecret-gay-code-to-popular-political-protest-129609.

Secrest, Meryle. Stephen Sondheim: a Life. Vintage Books, 2011.

Sondheim, Stephen, and George Furth. Company: a Musical. Theatre Communications Group, 1996.

Sondheim, Stephen, and Hugh Wheeler. A Little Night Music. Dodd, Mead \& Company, 1973. Sondheim, Stephen, and Hugh Wheeler. Sweeney Todd: the Demon Barber of Fleet Street. Applause Books, 1991. 
Sondheim, Stephen, and James Lapine. Into the Woods. Theatre Communications Group, 2006.

Sondheim, Stephen, and John Weidman. Road Show. Theatre Communications Group, 2009.

Sondheim, Stephen. Finishing the Hat: Collected Lyrics (1954-1981) with Attendant Comments, Principles, Heresies, Grudges, Whines and Anecdotes. Alfred A. Knopf, 2011.

Sondheim, Stephen. Look, I Made a Hat: Collected Lyrics (1981-2011), with Attendant Comments, Amplifications, Dogmas, Harangues, Digressions, Anecdotes and Miscellany. Alfred A. Knopf, 2011.

Speidel, Susan. "Extraordinary Women: Desiree, Petra and Madame Armfeldt Defy Expectations in Night Music.” The Sondheim Review, vol. 17, no. 2, 2010, pp. 29-30.

Stoddart, Scott F. "Queer Sondheim.” The Oxford Handbook of Sondheim Studies, edited by Robert Gordon, Oxford University Press, 2014, pp. 416-431.

Taft, Eleanore. "The Intersection of Burlesque and Feminism.” Little Village, 2016, littlevillagemag.com/the-intersection-of-burlesque-and-feminism/.

Taylor, Jodie. "Claiming Queer Territory in the Study of Subcultures and Popular Music.” Sociology Compass, vol. 7, no. 3, 2013, pp. 194-207., doi:10.1111/soc4.12021.

Turner, Jeff. “Commercial Necessities: Reviving Stephen Sondheim and George Furth's Company at the Turn of the Millennium." Theatre Symposium, vol. 22, no. 1, 2014, pp. 62-76., doi:10.1353/tsy.2014.0011.

University of Illinois. "LibGuides: Queer Theory: Background.” Background - Queer Theory, 2021, guides.library.illinois.edu/queertheory/background.

Wilson, Natalie. "The 'Both/And' Celebration of 'Into the Woods.”' Ms. Magazine, 2014, msmagazine.com/2014/12/22/the-bothand-celebration-of-into-the-woods/. Winer, Laurie. "Why Sondheim's Women Are Different." The New York Times, 1989. 
Wolf, Stacy Ellen. Changed for Good: a Feminist History of the Broadway Musical. Oxford University Press, 2011.

Zuckerman, Esther. “Stephen Sondheim Reworking Seminal 'Company' to Make Lead Gay.” The Atlantic, 2013. 